\title{
Notas sobre "Cálice" (2010, 1973, 1978, 2011)
}

\section{WALTER GARCIA*}

\begin{abstract}
RESUMO: O artigo tem por objetivo discutir a forma artística e a atuação mercadológica da canção "Cálice" (Gilberto Gil/ Chico Buarque), em 1973 e em 1978, do vídeo Criolo Doido - Cálice, de 2010, e da canção "Rap de Cálice" (Chico Buarque), de 2011. Na perspectiva que se adota, a noção de forma se refere tanto à análise dos elementos que estruturam determinada obra quanto à interpretação do sentido de tal estrutura à luz do processo histórico brasileiro. Assim, recursos musicais e poéticos de "Cálice", Criolo Doido - Cálice e "Rap de Cálice", bem como as relações entre esses recursos e alguns aspectos fundamentais das atuações de Chico Buarque, Gilberto Gil, Milton Nascimento e Criolo no mercado, são interpretados à luz do processo histórico brasileiro na década de 1970 e na atualidade.
\end{abstract}

PALAVRAS-CHAVE: Chico Buarque; Gilberto Gil; Milton Nascimento; Criolo; canção popular brasileira; sociedade brasileira contemporânea.

\section{Notes on "Cálice" (2010, 1973, 1978, 2011)}

\begin{abstract}
The paper analyses fundamentals aspects of the artistic form and the marketing perform of the song "Cálice" (Gilberto Gil/ Chico Buarque), composed in 1973 and recorded in 1978, of the clip Criolo Doido - Cálice, recorded in 2010, and of the song "Rap de Cálice" (Chico Buarque), recorded in 2011. In the perspective that one takes, the notion of form refers to the analysis of the elements that structure each composition and to the interpretation of the meaning of that structure in the light of Brazil's historical process. Thus, some musical and poetical techniques of "Cálice", Criolo Doido - Cálice and "Rap de Cálice", as well as the relationships between these techniques and some key aspects of the performances of Chico Buarque, Gilberto Gil, Milton Nascimento and Criolo in the market, are studied in the light of Brazilian history in the 1970s and in our days.
\end{abstract}

KEYWORDS: Chico Buarque; Gilberto Gil; Milton Nascimento; Criolo; Brazilian popular music; Brazilian contemporary society.

\footnotetext{
* Walter Garcia é professor da área de Música do Instituto de Estudos Brasileiros (IEB) da USP. É mestre e doutor em Literatura Brasileira pela USP. Autor dos livros Melancolias, mercadorias: Dorival Caymmi, Chico Buarque, o pregão de rua e a canção popular-comercial no Brasil (São Paulo: Ateliê Editorial, 2013) e Bim Bom: a contradição sem conflitos de João Gilberto (São Paulo: Paz e Terra, 1999), além de vários artigos sobre canção popular brasileira. Organizador do livro João Gilberto (São Paulo: Cosac Naify, 2012). Compositor e violonista, atualmente trabalha no projeto autoral $\mathrm{Na}$ Cachola com a cantora e compositora Marília Calderón. E-mail: waltergarcia@usp.br
} 


\section{Setembro de 2010, YouTube.}

riolo Doido está dentro de uma lanchonete, parado em frente ao balcão. À
esquerda, fora de foco, produtos que se aglomeram no caixa (cigarros,
isqueiros, lâminas de barbear descartáveis, chocolates), além do logotipo do cartão Visa. Atrás, também à esquerda e fora de foco, uma prateleira vermelha com embalagens de salgadinhos, as cores berrantes em contraste com a roupa escura do rapper, jaqueta chumbo, com riscos brancos e cinza, fechada sobre uma camiseta preta. A gravação é feita da perspectiva de quem se encontra ao lado do caixa, de pé como Criolo, a pouca distância. Ele entoa versos criados em cima de "Cálice" (Gilberto Gil/ Chico Buarque). Olha para vários pontos. Com um gesto, pede a um funcionário que lhe sirva e agradece. Ao final, levanta uma tampa de plástico, espia o que parece ser um bolo em uma bandeja.

\section{Maio de 1973, Jornal do Brasil.}

"Cálice" foi composta quando Gilberto Gil e Chico Buarque receberam "a tarefa de compor e cantar uma música em dupla" no Phono 73, evento promovido pela gravadora de ambos no Palácio de Convenções do Parque Anhembi, em São Paulo (GIL, 2003, p. 161). Em 10 de maio de 1973, primeiro dos quatro dias do Phono 73, o Jornal de Brasil publicou uma notícia com o título "Chico Buarque e Gilberto Gil cantam juntos pela primeira vez em São Paulo", na qual se definia o evento como um "festival-feira".

Não tenho condições de avaliar em que medida a sucursal de São Paulo, que assina a matéria, utilizou release distribuído pela Philips. Certo é que o texto se limitava basicamente a divulgar os shows:1 "a Companhia Brasileira de Discos Phonogram² reunirá 30 dos mais importantes nomes da música popular brasileira

\footnotetext{
1 A divulgação, todavia, se equivocava ao informar que Gilberto Gil "hoje, às 21 horas, estará, pela primeira vez, cantando junto num palco com Chico Buarque de Holanda". Ambos se apresentariam no dia seguinte, 11 de maio de 1973, sexta-feira.

2 A Phonogram surgiu em 1945, quando "a filial francesa da Gramophone passou para o controle da Philips, empresa do setor elétrico", no quadro de "uma sequência de fusões" que marcaram, de 1928 a
} 
numa exposição sem caráter competitivo". Seja como for, "festival-feira" é uma definição que merece ser analisada, pois aglutina duas palavras correntes entre produtores, intermediários (jornalistas, apresentadores) e público desde a movimentação da bossa nova. O termo "festival" ficou bastante conhecido, sabe-se, durante o processo de consolidação da sigla MPB, quando cancionistas passaram a disputar o Festival da Música Popular Brasileira (TV Record, 1965-1969) ou o Festival Internacional da Canção (TV Globo, 1966-1972) como se encenassem “espetáculos de luta livre". 3 Daí a notícia do Jornal do Brasil esclarecer que Phono 73 seria uma “exposição sem caráter competitivo". Mas já em 22 de setembro de 1959 fora

1945, “a interação da produção dos formatos e de seus reprodutores" (DIAS, 2008, p. 39-40). Em 1958, a Philips adquiriu a Companhia Brasileira de Discos, a qual se originara, em 1955, da Sinter Sociedade Interamericana de Representações -, empresa fundada em 1945 (UNIVERSAL MUSIC, 2014). Na década de 1960, é adquirido o selo Elenco, de Aloysio de Oliveira, "uma das experiências mais bem sucedidas da época, em termos de qualidade da produção e lançamento (...), mas que naufragou sem recursos frente à Philips nas mãos de Armando Pittigliani" (COLETIVO MPB, 2006). Em 1978, com a fusão da Phonogram e da Polydor, surge a PolyGram, "braço fonográfico da Philips, (...) empresa transnacional do setor eletro-eletrônico, administrada basicamente por capital holandês e alemão" (DIAS, 2008, p. 46). Em 1998, "os 75\% de participação na Polygram pertencentes à Philips" são comprados pelo grupo canadense Seagram, conhecido "como uma companhia de bebidas" (FOLHA DE S.PAULO, 22 mai. 1998), "dono de marcas como a vodca Absolut e o uísque Chivas" (FOLHA DE S.PAULO, 11 nov. 1998). O grupo Seagram, que havia adquirido a Universal Studios há dois anos, expandia "suas atividades na indústria do entretenimento" (FOLHA DE S.PAULO, 22 mai. 1998). Com a compra da PolyGram, surge a Universal Music. Para Marcia Tosta Dias, "o movimento revelou a opção da Philips pela produção de hardware por considerar que, ao produzir gravadores de CDs, estaria trabalhando contra seu próprio negócio fonográfico. A quebra na interação entre hardware e software expressa a profundidade das mudanças, pois altera de maneira radical o núcleo que historicamente sustentou o poder das empresas" (DIAS, 2008, p. 184). Em 2000, a Universal Music é adquirida pelo grupo francês Vivendi (FOLHA DE S.PAULO, 1 jul. 2000).

${ }^{3}$ O comentário é de Paulinho Machado de Carvalho, que assumiu o cargo de diretor-executivo da TV Record em 1964, permanecendo à frente da emissora até 1990, quando as ações foram compradas por Edir Macedo. É certo que esse comentário de "Seu Paulinho", como era chamado na Record, deve ser contraposto a outro, feito na mesma entrevista: "Depois, a bola de neve foi crescendo tanto que ficou maior do que um programa de televisão, ficou maior do que a própria empresa e quase, posso dizer, do que São Paulo". Todavia a contraposição não altera o ponto de vista, tão revelador quanto previsível, de um diretor-executivo: "além das músicas [com aquela qualidade], haveria o confronto pessoal entre um segmento que um artista representava e outro segmento representado por outro artista" (TERRA; CALIL, 2013, p. 55-56). Para melhor compreensão dos vínculos entre a consolidação do sistema da MPB (seus cancionistas, suas obras e seus públicos) e os festivais televisivos, devem ser consideradas observações de Marcos Napolitano sobre "o sentido histórico" do III Festival da Música Popular Brasileira, produzido e veiculado pela Record em 1967: "A mitologia em torno dos festivais consagrou a ideia de um público consciente do que queria, mas esta característica não pode ser generalizada. Fã-clubes, empatias espontâneas, grupos politicamente orientados, idiossincrasias de toda ordem parecem estar presentes no comportamento do público no auditório (...). Grosso modo, [nas análises da imprensa e nas declarações dos artistas], nota-se que o Festival foi supervalorizado na sua dimensão de esfera pública não-oficial, como se o fato de ser, basicamente, um evento comercial e televisual fosse um mero acidente" (NAPOLITANO, 2001, p. 203-204). 
apresentado o $1^{0}$ festival de samba-session, no anfiteatro da Faculdade Nacional de Arquitetura, show com entrada gratuita organizado por estudantes de Direito da Pontifícia Universidade Católica do Rio de Janeiro. Segundo Ruy Castro, "na hora de dar um nome ao espetáculo", os universitários "se inspiraram no Festival de Jazz realizado em junho no Teatro Municipal" (CASTRO, 1999, p. 221-230). Seguiram-se outros shows para estudantes no Rio, mas o termo "festival" foi retirado dos nomes: em 13 de novembro de 1959, houve o Segundo comando da operação bossa nova na Escola Naval (CASTRO, 1999, p. 230-231); em 20 de maio de 1960, a Noite do sambalanço, na Pontifícia Universidade Católica, e também A noite do amor, do sorriso e da flor, na Faculdade Nacional de Arquitetura; nesse último, todavia, o apresentador Ronaldo Bôscoli "anunciou ao microfone" que se tratava do "primeiro festival de Bossa Nova" (CASTRO, 1999, p. 263-266).

Note-se com que senso de oportunidade se divulgaram, nos nomes desses três shows que garimpavam público entre estudantes na zona sul carioca, palavras que já circulavam no mercado fonográfico hegemônico: a) a expressão "bossa nova", utilizada por Antonio Carlos Jobim e Newton Mendonça em "Desafinado", e por Jobim no texto para a contracapa do primeiro LP de João Gilberto, lançado pela gravadora Odeon em 1959 - “João Gilberto é um baiano, 'bossa-nova' de vinte e sete anos"; b) o termo "sambalanço", adotado por Carlos Lyra para designar seu próprio trabalho após assinar contrato com a Companhia Brasileira de Discos - Philips em 1960 (CASTRO, 1999, p. 262-263); c) “O amor, o sorriso e a flor”, título do segundo LP de João Gilberto, lançado pela Odeon também em 1960. Não por acaso, a Odeon participou da produção d' A noite do amor, do sorriso e da flor, e a Philips, da produção da Noite do sambalanço (CASTRO, 1999, p. 264).

À semelhança de outros momentos da canção popular, os títulos dos três shows cifravam a aspiração publicitária. É lógico que não se podia imaginar o sucesso comercial que algumas das canções apresentadas alcançariam no Brasil e no exterior. Apostava-se. O mesmo vale para as palavras então divulgadas, e "sambalanço" não pegou. Fazendo suas apostas, os nomes dos shows revelavam que a produção voltada para o comércio era uma das linhas de força das obras, o que não constituía grande novidade: procurar um comprador é dever da canção popular 
desde que as classes médias urbanas passaram a consumir partituras, discos e programas de rádio.

Em outras palavras, se toda e qualquer canção vive enquanto é entoada, e se um canto lírico - enquanto "expressão de emoções e disposições psíquicas" ou de “concepções, reflexões e visões" experimentadas pelo sujeito ou por um grupo - não requer necessariamente a presença física "de ouvintes ou interlocutores" (ROSENFELD, 2000a, p.24), a atuação da canção popular-comercial depende da existência de meios tecnológicos de transmissão e também da existência de um conjunto, mais restrito ou mais amplo, de receptores que lhe sustentem economicamente. Mas é preciso lembrar que essa competição pelo consumidor no mercado anônimo é uma situação que cabe, via de regra, aos artistas na chamada modernidade. ${ }^{4} \mathrm{E}$ "só porque uma obra de arte é uma mercadoria, ela não é somente ou imediatamente uma mercadoria" (BROWN, 2014). Para a crítica da canção de mercado, o trabalho é avaliar as consequências que determinada obra, em particular, retira da natureza comercial de sua produção.

Por ora, e nos limites deste artigo, atente-se para a diferença significativa entre dois momentos: o primeiro, quando da divulgação de um tipo de canção ou de um LP nos nomes de três shows para estudantes em 1959 e 1960; o segundo, quando da divulgação da própria gravadora no nome Phono 73, "festival-feira" levado ao Palácio de Convenções do Parque Anhembi. Entre um momento e o outro, dois títulos comprovam a boa aceitação, na década de 1960, do termo "festival" ligado a mostras "sem caráter competitivo": $1^{\circ}$ Festival de Bossa Nova, "realizado no Recife, sob o patrocínio dos Diretórios de Sociologia e Política do Instituto de Ciências Políticas e Sociais e da Escola de Serviço Social do Recife"; e Festival Bossa I, "realizado em Campina Grande, Paraíba" (BRITTO, 1966, p. 131 e 133).

Quanto a "feira", é evidente que a palavra se vincula às trocas comerciais, processo que realmente interessava, no fim das contas, à Phonogram. Logo após o evento, em 15 de maio de 1973, outra matéria da sucursal de São Paulo do Jornal do Brasil, "Phono 73 o festival sem competição", divulgava: "Não tendo sido televisado

\footnotetext{
${ }^{4}$ Adapto, para fins próprios, formulações de CANDIDO (2000; 1998), de BENJAMIN (2000) e de ROSENFELD (2000b).
} 
nem gravado para posterior apresentação em vídeo-tape,,$^{5}$ o Festival resultará no lançamento de um álbum especial de quatro LPs, a serem colocados no mercado até o final do ano" (os planos seriam alterados, e três LPs foram lançados sucessivamente). E o parágrafo final repercutia (no jargão jornalístico) a intenção liberal do empreendimento e também o seu interesse no mercado dos EUA:

\footnotetext{
A revista norte-americana Billboard publicará matéria especial sobre a Phono 73, que os dirigentes da Philips consideram, "se não revolucionário [sic] quanto às perspectivas abertas para a música brasileira em geral, pelo menos algo de diferente e de marcante, porque sem preconceitos" (JORNAL DO BRASIL, 15 mai. 1973, p. 4).
}

Mas "feira" também se tratava de termo corrente no quadro da "relativa hegemonia cultural da esquerda no país", para retomar a já célebre formulação de Roberto Schwarz em “Cultura e Política, 1964-1969" (SCHWARZ, 1992, p. 62). Caetano Veloso publicou o texto "Primeira feira de balanço" em Ângulos, revista dos alunos da Faculdade de Direito da Universidade Federal da Bahia, em 1965 (não sei dizer se o título do artigo citava uma mostra organizada pelos estudantes). E o Teatro de Arena de São Paulo organizou a Primeira Feira Paulista de Opinião em 1968.6

Voltando à notícia “Chico Buarque e Gilberto Gil cantam juntos pela primeira vez em São Paulo", a primeira frase dessa matéria do Jornal do Brasil vinha entre aspas. Tratava-se de uma declaração de Gil: “'Existem várias formas de fazer música brasileira. Eu prefiro todas'”. Será interessante cotejar a declaração do artista e o anúncio do Phono 73 que ocupava dois "tijolinhos" na página de classificados dos cadernos culturais.

\footnotetext{
${ }^{5}$ Segundo Caio Túlio Costa, "duas rádios paulistanas transmitiram o festival, ao vivo. A TV Cultura, canal 2, também" (COSTA, 2003, p. 165).

${ }^{6} \mathrm{O}$ artigo "Primeira feira de balanço" pode ser lido em VELOSO (2005, p. 143-153). Sobre a Primeira Feira Paulista de Opinião, ver os documentos escritos em 1968 por Augusto BOAL (24 nov. 2014) e por Cacilda BECKER (20 mar. 2014).
} 


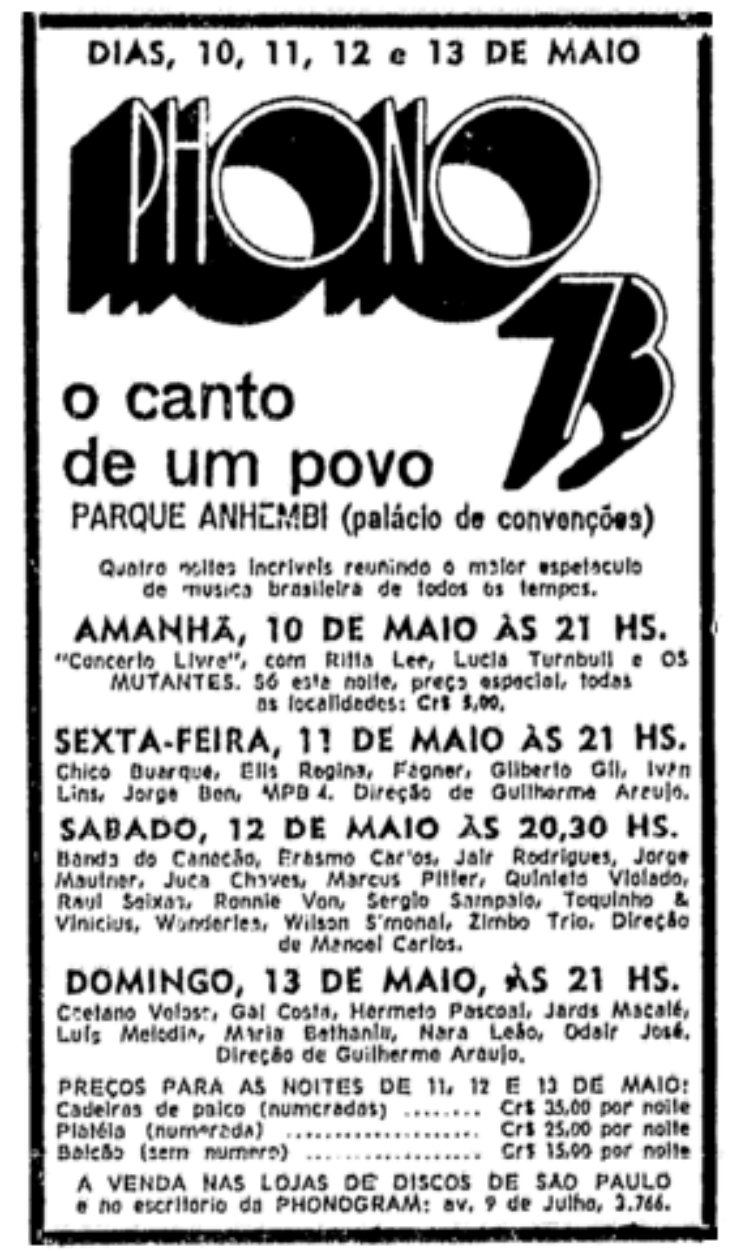

Ex.1 - Anúncio publicitário do Phono 73.

"O canto de um povo", um slogan, claramente vinculava o festival-feira à cultura politizada de esquerda que se adensara no início da década de 1960, tendo como marco principal, naquele período, a experiência do CPC (Centro Popular de Cultura) da UNE (União Nacional dos Estudantes), fundado em dezembro de 1961 e extinto com o golpe de $1964 .{ }^{7}$ De fato, as obras de Chico Buarque, Gilberto Gil, MPB4, Elis Regina, Caetano Veloso, Gal Costa, Nara Leão, entre outros contratados da Phonogram e participantes do Phono 73, levaram adiante aquela cultura a partir de 1964, em parte desdobrando (caso de Chico Buarque) ou refutando a experiência do CPC (caso dos tropicalistas). Na linha de Adorno (1998, p. 23), pode-se dizer que o slogan expressava uma intenção que não era verdadeira à medida que pretendesse "coincidir com a realidade", mas que era verdadeira à medida que anunciasse

\footnotetext{
7 Sobre o CPC da UNE, ver GARCIA (2007).
} 
projetos, mais ou menos diferentes entre si, de dar voz ao que se chama "povo" ou de estabelecer algum tipo de diálogo entre as classes médias urbanizadas, lugar social onde se firmavam os pontos de vista das canções, e as classes baixas.

Nessa perspectiva, tal processo variado de "'ida ao povo'" tentou "equacionar os impasses surgidos em torno do nacional-popular" (NAPOLITANO, 2001, p. 12-13). Nos limites deste artigo, o aspecto principal é que a variedade de soluções estéticas apresentadas por aqueles cancionistas geraram contrastes e tensões, não se ignora, nos festivais de caráter competitivo da TV Record ou da TV Globo em 1967 e, sobretudo, em 1968. Contrastes e tensões que se evaporavam, se não de fato, ao menos na estratégia da Phonogram ao promover o "feira-festival" em 1973. Sem exagero, pode-se afirmar que a declaração de Gil - “'Existem várias formas de fazer música brasileira. Eu prefiro todas'" - sintetizava com grande acerto a estratégia comercial da gravadora, de modo que bem poderia ter sido utilizada no próprio anúncio. ${ }^{8}$ Adiante retomarei o ponto.

Já a frase "Quatro noites incríveis reunindo o maior espetáculo de música brasileira de todos os tempos" estava bem de acordo com os manuais de redação publicitária. Enfileiravam-se qualidades superlativas, numa retórica que aparentemente retirava do consumidor qualquer chance de escolha: quem, em sã consciência, perderia uma só daquelas noites incríveis do maior espetáculo de todos os tempos? Por outro lado, o tamanho e a linguagem visual do anúncio eram acanhados.

\footnotetext{
${ }^{8}$ Não deixa de ser interessante notar certa semelhança entre a declaração de Gilberto Gil e dois slogans veiculados décadas adiante: a) "Existem mil maneiras de preparar Neston, invente uma!", frase que obviamente busca atribuir ao ato de consumir a mercadoria o valor de um ato criativo (e, por conseguinte, o valor da liberdade - cujo ápice de utilização para fins comerciais talvez tenha sido alcançado pelo jingle, de 1976, "Liberdade é uma calça velha/ Azul e desbotada/ Que você pode usar/ Do jeito que quiser/ Não usa quem não quer/ US Top/ Desbota e perde o vinco/ Denim Índigo Blue/ US Top/ Seu jeito de viver"); b) "Amo muito tudo isso!", slogan do McDonald's que obviamente celebra a mercadoria padronizada enquanto objeto do desejo - embora de modo muito conciso, um exemplo do atual processo de "imperativo do gozo" e de apagamento das diferenças subjetivas (KEHL, 2004, p. 74). Diga-se de passagem, "Amo muito tudo isso!" é uma maneira mais enfática de dizer "Gosto do que acontece", frase "do intelectual Rogério Duarte" que, segundo Caetano Veloso, "resume bem" a sua própria atitude e pode ser vinculada à tropicália: "Os valores críticos que você desenvolve são muito provisórios e estão desarmados diante do frescor da realidade. Desse sentimento, nasceu o tropicalismo. Para todo mundo da minha geração, gostar do Roberto e do Erasmo Carlos era um anátema. Você não podia nem remotamente aprovar o que se passava na Jovem Guarda. De repente, ao abrir mão do preconceito, nos permitimos ver o que havia naquele cenário e aquilo nos interessou. Gostávamos do que acontecia - e ainda gosto" (HECKLER, 2011, p. 33). Para relações entre o trabalho de composição de Gilberto Gil e "ideias do slogan e do jingle", segundo o próprio compositor, ver GIL (2003, p. 184-185; 205-206).
} 
Tratava-se, afinal, de dois tijolinhos em preto e branco, sem qualquer ilustração, na página de classificados. Apenas o logotipo do Phono 73 se destacava. Uma publicidade bastante modesta se comparada, p. ex., ao anúncio da coleção de roupas Jovem Guarda, estrelado por Roberto Carlos e veiculado em cores, em página inteira, na revista Reportagem, em dezembro de 1966 (COLEÇÃO JOVEM GUARDA, 1966, p. 171). Ou à foto de Chico Buarque (fazendo pose semelhante à de João Gilberto na capa do LP Chega de saudade), também em cores e em página inteira, abrindo a matéria “Chico dá samba” no mesmo número da revista (FREIRE, 1966, p. 68).

\section{1 de maio de 1973, Palácio de Convenções do Parque Anhembi}

Em 29 de abril e em 7 de maio, na sua coluna social no Caderno B do Jornal do Brasil, Zózimo Barroso do Amaral publicou notas sobre "Cálice". A primeira somente informava que Phono 73 revelaria "algumas parcerias musicais inéditas, entre elas Chico Buarque-Gilberto Gil e Jorge Ben-Gil”. A segunda nota, publicada quatro dias antes do show, indica a arbitrariedade que marcou a atuação do aparelho repressivo durante a ditadura:

Chico Buarque e Gilberto Gil - parceiros pela primeira vez na música Cálice - esperam a palavra final da Censura para ensaiarem a apresentação da nova composição na Phono 73, festival que a Philips organiza em São Paulo esta semana.

Segundo a Phonogram, a letra de "Cálice" "foi encaminhada aos seus escritórios no dia 3" de maio, sendo então levada ao Serviço de Censura, na Guanabara. Como não foi liberada, a gravadora "enviou a letra ao Serviço de Censura em São Paulo, tentando uma autorização apenas para ela ser apresentada na Phono 73", o que foi negado (FOLHA DE S.PAULO, 18 mai. 1973). Deve-se ter em conta que “a Censura agiu com extremo rigor" nos anos de 1973 e 1974, período em que também foi registrado o maior "número de pessoas desaparecidas" (SILVA, 2008, p. 93). Conforme Carlos Nelson Coutinho observava em 1979, 
A prática sistemática da censura, aliada e um claro terrorismo ideológico, pode ser considerada como a face aberta da "política cultural" vigente após 1964 e, em particular, no período posterior a 1968, ou seja, à decretação do AI-5. Seria simplista reduzir a isso o quadro das relações entre a cultura e a sociedade nos últimos anos; mas será ainda mais perigoso esquecer que tal face condicionou, através certamente de múltiplas mediações, a totalidade da produção cultural sob a vigência do regime militar (COUTINHO, 2013, p. $54)$.

A censura a "Cálice" e a tentativa de apresentação da sua parte musical, na noite de 11 de maio de 1973, já foram pesquisadas e, para o que aqui se discute, não é preciso retomar mais do que o essencial. ${ }^{9}$ No Phono 73, os dois compositores tocaram violão e cantarolaram a melodia das estrofes (parte B) utilizando-se de uma espécie de grammelot. Foram registrados ou editados 3:27 de áudio - não há registro de imagens em igual tempo no DVD que a Universal Music lançou em 2005. A forma musical completa de "Cálice", no material reunido nesse DVD, é: introdução (solo de Gilberto Gil ao violão);

A (Gil entoa em grammelot; Chico canta a letra de modo um tanto enrolado);

B, B (Gil entoa em grammelot; Chico pontua as frases de Gil com a palavra "Cálice"; público aplaude);

A (Chico canta a letra de modo claro e fica sem som por um momento; Gil entoa em grammelot);

B, B (Chico entoa "arroz à grega, paracundá"; Chico e Gil entoam em grammelot; Chico grita "Meu som!" antes da repetição da parte B);

A (Chico canta a letra de modo claro; escutam-se palmas);

B, B (ambos entoam em grammelot; Chico pergunta "Tem som?" em 2:45, e respondem "Não!" da plateia; ouvem-se ruídos nos microfones em 3:04);

A (Chico canta a letra de modo claro; ao final, ruídos nos microfones e palmas).

$\mathrm{Na}$ recordação de Aquiles, um dos integrantes do MPB4, grupo que acompanhou Chico Buarque no Phono 73,

Cantados os primeiros versos [de "Cálice"], os microfones "misteriosamente" emudeceram. Percebendo a manobra, nós mesmos, no palco, diante da plateia atônita, começamos a substituir por outros os microfones emudecidos pelos agentes federais [na cabine de som do Anhembi]. Foi uma sequência angustiante de "emudecimentos". Ao final da batalha, um mar de microfones mudos com os cantores, os compositores e o público. Essa nós perdemos e choramos de raiva (REIS, 2004, p. 91).

\footnotetext{
9 Ver SILVA (2008, p. 127-128), COSTA (2003, p. 157-170), ARAÚJO (2002, p. 203-206), MENESES
} (2000, p. 91-92). 
Não há imagens das substituições de microfones no DVD, mas presumivelmente os ruídos em 3:04 se devem a isso. Com base no áudio, não é possível conferir o "mar de microfones mudos". No último refrão, "Cálice" se interrompe logo após o verso "De vinho tinto de sangue", e escutam-se novamente ruídos nos microfones. Mas a questão não é se a recordação de Aquiles, atravessada de afetos, deve ou não ser tomada ao pé da letra. Fundamental é o fato de que, frente à Censura e à sua arbitrariedade, houve certa resistência por parte dos compositores e dos músicos no palco. ${ }^{10}$ Afinal, segundo afirmaram Chico e Gil em “O CÁLICE da discórdia", matéria publicada pelo Jornal do Brasil em 15 de maio de 1973, quatro dias após a apresentação no Phono 73: “A melodia não foi proibida, ao que nos consta, e sim, a letra". Presume-se, a letra das estrofes, uma vez que a letra do refrão, como se sabe, se apropria dos Evangelhos. ${ }^{11}$

Chico Buarque atribuiu à Phonogram o corte do som e disse que deixaria a gravadora (FOLHA DE S.PAULO, 16 mai. 1973). Manteve-se na Philips, contudo, até 1980, apesar de "sucessivos entreveros" desde o festival-feira (WERNECK, 2000, p. 131-132). Já a Phonogram enviou uma “carta de esclarecimentos" à imprensa em 17 de maio de 1973, na qual declarava: “Pouco antes da apresentação de Chico, dois dos quatro fiscais presentes se dirigiram às mesas de som. Quando o cantor começou a solfejar a música e a cantar a palavra Cálice, a Censura passou a agir, cortando o som" (FOLHA DE S.PAULO, 18 mai. 1973).

Em "O CÁLICE da discórdia”, Gilberto Gil ainda afirmou, com aparente simplicidade: “Da Phono nada saiu ou sairá de revolucionário, quanto à pesquisa ou criação. Mas o importante é que quase 30 artistas cantaram juntos, e é importante que a gente possa e consiga cantar". Digo "aparente simplicidade"

\footnotetext{
10 Gilberto Gil chamaria, décadas adiante, a apresentação de "desobediência civil" (GIL, 2003, p. 162). Caio Túlio Costa recriou uma conversa de dois alunos, em reunião do CCA (Conselho de Centros Acadêmicos) da USP, logo após "a atitude contestatória de Gilberto Gil e Chico Buarque no Phono 73": “- Tá certo, eles não conseguiram cantar o Cálice, mas tentaram. - Desafiaram a ordem" (COSTA, 2003, p. 182).

11 Para o verso "Pai, afasta de mim esse cálice", ver Mateus 26, 39; Marcos, 14, 36; Lucas, 22, 42. Para "De vinho tinto de sangue", ver Lucas, 22, 44. A letra integral de "Cálice" foi publicada na coluna "Música Popular", de Julio Hungria, no Jornal do Brasil de domingo, 13 de maio de 1973 (HUNGRIA, 13 mai. 1973). Segundo Caio Túlio Costa, a íntegra da letra também foi publicada pelo Jornal da Tarde em 12 de maio de 1973 e, uma semana depois, por A Ponte, jornal mural do CCA da USP (COSTA, 2003, p. 192, 210 e 318).
} 
porque a afirmação condensava diversas tensões acenando com a possibilidade de harmonia.

Em primeiro lugar - e não há de ter escapado a quem acompanha este artigo com atenção -, a julgar por duas matérias publicadas lado a lado no Jornal do Brasil em 15 de maio de 1973, Gilberto Gil e os dirigentes da Philips se afinavam na resposta à expectativa de que o festival-feira trouxesse inovações estéticas: "nada saiu ou sairá de revolucionário", todavia a mostra foi "pelo menos algo de diferente e de marcante, porque sem preconceitos". É preciso lembrar que, na época, entre artistas e intelectuais havia a ideia de que um "vazio cultural" - ou a ideia de que uma "cultura esvaziada" (COUTINHO, 2013, p. 54) - se instalara no Brasil após a edição do Ato Institucional no 5, em 13 de dezembro de 1968,

através de uma implacável ação que se exerceu em dois planos. Com a censura prévia agindo no interior do campo cultural - cortando, expurgando ou simplesmente vetando -, pôde exercer-se um rigoroso trabalho de prevenção; com os outros poderes que transcendem a cultura - cassação, expulsão, aposentadoria e prisão -, pôde instaurar-se um inapelável mecanismo de punição (VENTURA, 2000, p. 43)

E ainda havia o receio de que a criação artística pudesse se transformar, em razão da censura prévia, em "um deserto sem cultura, por medo de criar. Seria o reino da autocensura (...), da ordem, do conformismo e da obediência"; um caminho para a "paz dos cemitérios" (VENTURA, 2000, p. 55).

Em segundo lugar, a afirmação de Gil aludia à "resistência cultural" enquanto estratégia de crítica e de oposição à ditadura. Estratégia "percebida como legítima e como espaço de convergência" por projetos estéticos e políticos mais ou menos divergentes entre si (NAPOLITANO, 2013, p. 319). ${ }^{12}$ Nessa chave, ganha outro sentido a declaração “'Existem várias formas de fazer música brasileira. Eu prefiro todas'”, retomada por Gil na matéria "O CÁLICE da discórdia".

Em terceiro lugar, veja-se que a declaração era agora retomada da seguinte forma:

\footnotetext{
12 Ver COSTA (2003) para um relato jornalístico do "abandono definitivo da luta armada em favor de uma política pacífica de mobilização das massas" e da "participação cultural com sentido político" entre estudantes da USP, promovendo-se então montagens teatrais, espetáculos de dança, ciclos de cinema e shows musicais - com destaque para a apresentação de Gilberto Gil em 26 de maio de 1973, no Biênio da Póli.
} 
Os dois compositores-intérpretes participaram, contentes, da Phono 73 "uma ótima oportunidade de reencontro com toda a patota ou, pelo menos, parte dela", diz Chico; e complementa Gil: "A vantagem é que a gente viu todas as formas de fazer música brasileira e eu já afirmei que de todas prefiro exatamente todas" (JORNAL DO BRASIL, 15 mai. 1973, p. 4).

Não se deve dar peso demasiado a afirmações publicadas na imprensa, sujeitas que estão não só ao caráter momentâneo das entrevistas como ao próprio filtro jornalístico. De todo modo, é notável a substituição de "várias formas" por "todas as formas de fazer música brasileira", um evidente exagero que atribuía ao festival-feira abrangência incrível. Em 1974, André Midani, então presidente da Phonogram, diria sobre a empresa: “em 1968 havia 170 empregados para 150 artistas, em 1974 serão 500 empregados para 28 artistas" ${ }^{13}$ E em 2005, relembrando a sua gestão para entrevista publicada no encarte da caixa Phono 73, Midani afirmou:

\begin{abstract}
Quando eu entrei na companhia, em abril de 1968, vindo do México, a empresa tinha algo como 150, 160 artistas contratados. Logo imaginei que era impossível lidar com esse número a contento, sobretudo o que chamamos de artista bom. Os que chamamos de não tão bons estavam disponíveis. Uma quantidade grande passava seu dia na gravadora. Esses eram evidentemente os menos bons. A primeira coisa que fiz foi pegar as gravações dos 160 artistas e, em casa, tranquilamente, ouvir... ouvir... isso demorou umas três semanas.

Daí, se a minha memória é boa, ficamos com uns 50 e poucos, o que pelos padrões da época eram poucos artistas. Entre esses apareceram Gil, Caetano, Gal, Elis, que estavam querendo sair da companhia, com toda razão, porque não estavam recebendo a atenção que mereciam. Então, fiz essa primeira peneira. E a segunda coisa foi separar o que posteriormente viria a se chamar de MPB do que seria chamado de música popular, em dois selos. Philips para um e Polydor para outro (VÁRIOS, 2005).
\end{abstract}

As peneiras realizadas pela gravadora, ao firmar contratos com artistas e, mais tarde, ao definir as apresentações do Phono 73, obviamente não selecionaram "todas as formas de fazer música brasileira". O que a declaração de Gilberto Gil, segundo o texto do Jornal do Brasil, escondia com seu exagero era a concorrência no mercado capitalista. Mercado cuja ideologia (no sentido de imagem invertida da realidade) acena com "Calma, minha gente, há lugar para todos!", e cujo funcionamento celebra, mesmo em uma "exposição sem caráter competitivo", alguns

\footnotetext{
${ }^{13}$ A declaração de André Midani foi apresentada por Enor Paiano, em sua dissertação Berimbau e som universal: lutas culturais e indústria fonográfica nos anos 60, e reproduzida por Marcia Tosta DIAS (2008, p. 108).
} 
poucos premiados - como as décadas posteriores à de 1970 nos mostraram, o número de artistas premiados e o valor dos prêmios, ou seja, o total de capital investido em cada trabalho, variam conforme a maré econômica. ${ }^{14}$ Adiante retomarei o ponto, ao abordar a utopia projetada pela tropicália.

É preciso lembrar outra ideia discutida por artistas e intelectuais, no início dos anos 1970, no debate sobre o "vazio cultural":

independentemente do AI-5, a cultura vive uma fase de transição em que, como superestrutura, tenta adaptar-se às alterações infra-estruturais surgidas no país. (...) Assim, na música popular, a interrupção do rico processo inventivo começado pela Bossa Nova de João Gilberto e depois retomado por Caetano e Gil teria como causa a massificação e não uma crise de criação (VENTURA, 2000, p. 47 e 49).

Zuenir Ventura notava que "o traço mais marcante" da cultura brasileira era a "falta de tendências coletivas ou movimentos" no enfrentamento do "dilema do vazio". Ainda assim, em texto publicado em agosto de 1973, identificava

se não caminhos, pelo menos três direções, que às vezes se confundem e se sobrepõem, uma adquirindo características da outra:

. Uma cultura de massa digestiva, comercial, de simples entretenimento;

- Uma contracultura buscando nos subterrâneos do consumo, mas frequentemente sendo absorvida por este, formas novas de expressão e de sobrevivência.

. Uma cultura explicitamente crítica, tentando olhar para a realidade política e social imediata (VENTURA, 2000, p. 60).

Se "Cálice" pode ser enquadrada, a princípio sem grandes discussões, na terceira direção identificada por Ventura, a articulação entre todas as características se faria notar no convite de Caetano Veloso a Odair José (cujos discos saíam pelo selo Polydor) para cantarem juntos no Phono 73. A plateia do Palácio de Convenções vaiou muito. Dois anos depois, Caetano escreveria:

Para que alguém possa fazer qualquer coisa assim como Jóia é preciso que as gravadoras tenham Odair e Agnaldo: o universitário que tenta me entrevistar e salvar a humanidade fica indignado diante do meu absoluto respeito profissional e interesse estético pelo trabalho de colegas meus como Odair José e Agnaldo Timóteo. Centenas de novos compositores e cantores e dezenas de velhos músicos não encontram lugar no mercado (VELOSO, 2005, p. 99).

\footnotetext{
${ }^{14}$ Sobre o assunto, ver DIAS (2008).
} 
É necessário aprofundar o entendimento da tentativa de apresentação de "Cálice" no festival-feira. Sem dúvida, a canção era "explicitamente crítica" e olhava "para a realidade política e social imediata". O que não significa que atuasse à margem dos "subterrâneos do consumo", muito embora não fosse "absorvida por este" justamente pelo teor de crítica e pelo caráter de resistência que constituíam tanto a sua forma quanto a tentativa de sua apresentação. Entretanto não custa sublinhar, a composição "sobre a dor, sobre o tormento, sobre a repressão, sobre a censura" (GIL, 15 abr. 2013) atendeu a uma tarefa da gravadora que concentrava os principais nomes da chamada $\mathrm{MPB}$, a qual, para a grande indústria, em essência era um segmento de consumo em articulação com os demais segmentos, sobretudo com o da chamada música popular cafona. ${ }^{15} \mathrm{Na}$ perspectiva da "engrenagem empresarial" do pós-1964, liberal e orientada fundamentalmente para o mercado, a Censura era nociva à medida que prejudicasse os negócios (ORTIZ, 2014, p. 122).

Marcos Napolitano vem pesquisando, com grande acuidade, o papel complexo e paradoxal da MPB na reorganização do mercado naquele período. Será útil transcrever uma passagem de seu artigo "A música popular brasileira (MPB) dos anos 70: resistência política e consumo cultural":

As imagens de "modernidade", "liberdade", "justiça social" e as ideologias socialmente emancipatórias como um todo impregnaram as canções de MPB sobretudo na fase mais autoritária do Regime Militar, situada entre 1969 e 1975. Além dessa perspectiva político-cultural moldada pela audiência, a consolidação da MPB como "instituição" se deu a partir da relação intrínseca com a reorganização da indústria cultural, a qual agiu como fator

\footnotetext{
${ }^{15}$ Quem primeiro chamou a atenção para a passagem do texto "Mil Tons", de Caetano Veloso, foi Paulo César de Araújo, em meio à sua análise da relação, na década de 1970, entre "dois grupos de cantores/compositores: aqueles considerados de 'prestígio' - que dão status à gravadora e alimentam sua imagem de produtora de objetos culturais - e aqueles considerados meramente 'comerciais' - que dão retorno financeiro grande e imediato" (ARAÚJO, 2002, p. 189-195). De modo mais amplo, a "mudança na atuação da indústria quando, no início dos anos 70, passa a investir em um cast estável, com artistas ligados à MPB, que produzem discos com venda garantida por vários anos, mesmo que em pequenas quantidades", bem como a relação entre esses "artistas de catálogo" (ou "artistas autênticos" ou "artistas verdadeiros") e os artistas de marketing foram pesquisadas por Marcia Tosta Dias: "O artista de marketing é o que é concebido e produzido, ele, o seu produto e todo o esquema promocional que o envolve, a um custo relativamente baixo, com o objetivo de fazer sucesso, vender milhares de cópias, mesmo que por um tempo reduzido (...) Dessa forma, a indústria gera, com velocidade e competência, grande quantidade de produtos que serão veiculados à exaustão e substituídos de acordo com os índices de vendagem alcançados. (...) A repetição das mesmas fórmulas (para não dizer da mesma fórmula) cativa o consumidor pela situação de conforto e familiaridade promovidas pelo reconhecimento, como foi apontado por alguns autores, e, dessa forma, garante à indústria um lucrativo e imediato retorno financeiro" (DIAS, 2008, p. 82 e 94).
} 
estruturante de grande importância no processo como um todo e não apenas como um elemento externo ao campo musical que "cooptou" e "deturpou" a cultura musical do país. O ouvinte padrão de MPB, o jovem de classe média com acesso ao ensino médio e superior, projetou no consumo da canção as ambiguidades e valores de sua classe social. Ao mesmo tempo, a MPB, mais do que reflexo das estruturas sociais, foi um polo fundamental na configuração do imaginário sociopolítico da classe média progressista submetida ao controle do Regime Militar (NAPOLITANO, 2002, p. 3). ${ }^{16}$

Sintetizando e mudando o foco: no Phono 73, "Cálice" concentrava resistência política e oportunidade comercial.

Quanto à declaração de Gilberto Gil “'Existem várias formas de fazer música brasileira. Eu prefiro todas'", acabaria abrindo "Manifesto", texto publicado na contracapa dos LPs que reuniram parte das apresentações do festival-feira. ${ }^{17}$

\footnotetext{
16 Uma vez que este artigo trabalha com textos jornalísticos e peças publicitárias, vale a pena lembrar que Marcos Napolitano, em "MPB: a trilha sonora da abertura política (1975-1982)", nos deu um excelente exemplo, por meio da citação de um anúncio, do papel da MPB no mercado hegemônico: “Na propaganda de aparelho de som da alta tecnologia, publicada na revista IstoÉ, em 23 de junho de 1977, lia-se a seguinte chamada: 'Para ouvir canções de protesto contra a sociedade de consumo, nada melhor do que um Gradiente financiado em 24 vezes'. Essa provocação publicitária, de certa maneira, expressava a condição paradoxal da música popular brasileira naquela década marcada pelo autoritarismo: foco da resistência e da identidade cultural de uma oposição civil ao regime militar, as canções rotuladas como parte da 'MPB - Música Popular Brasileira' eram extremamente valorizadas pela indústria fonográfica brasileira" (NAPOLITANO, 2010, p. 389).

${ }_{17}$ Como se disse, em 1973, a Phonogram lançou sucessivamente três LPs com parte do áudio do Phono 73. Em 2005, a Universal Music lançou uma caixa com dois CDs, os quais reeditam o conteúdo daqueles LPS, e um DVD, que traz imagens da mostra até então inéditas. O "Manifesto" também está reproduzido nessa caixa.
} 


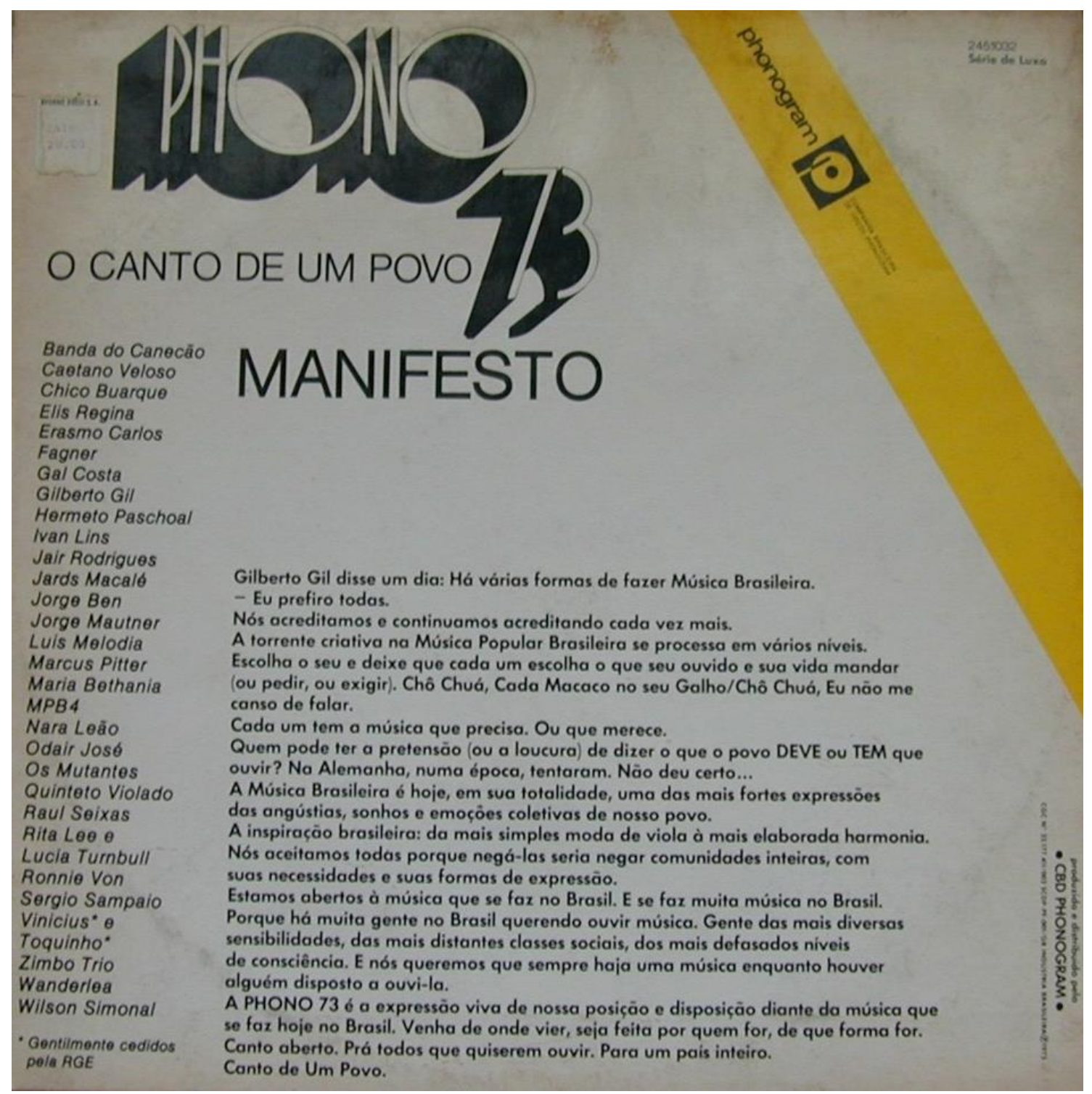

Ex.2 - Contracapa do LP Phono 73: o canto de um povo.

A retórica buscava conjugar política e estética desde o título, mas escancarava essa busca quando aludia à Alemanha durante o governo nazista modo pouco sutil de qualificar o autoritarismo da Censura - ou quando mencionava a existência, no Brasil, de classes sociais as "mais distantes". Desse ângulo, o "Manifesto" ainda reverberava aquela "relativa hegemonia cultural da esquerda no país", dando continuidade, à sua maneira, ao grande negócio em que se transformara a "produção de esquerda" a partir de 1950 (SCHWARZ, 1978, p. 62-67). ${ }^{18}$ Abrindo o

18 Para Iná Camargo Costa, "o fenômeno da mercantilização da luta política" esteve presente desde o show Opinião e o disco homônimo resultante. Na sua avaliação, a vendagem do LP "revelou aos atentos executivos a existência de um grande público (para os padrões vigentes), cujo perfil foi esquematizado a partir da ideia de 'universitário padrão', disposto a consumir o samba 'de raízes', até 
texto, a força da declaração de Gilberto Gil advinha, em parte, de uma utopia que a tropicália projetara em seus anos de combate (1967-1968). Muito sinteticamente, utopia que pode ser melhor compreendida se vista em duas etapas: de um lado, a afirmação do Brasil enquanto potência cultural, superior pela grandeza estética da sua identidade; de outro, a afirmação da identidade brasileira enquanto harmonia da diversidade cultural. A utopia da tropicália, dizendo ainda muito sinteticamente, nasceu da distância entre o ideal do liberalismo e a constituição concreta do mercado capitalista. Por isso mesmo, sempre houve algum grau de engano quando se acreditou que essa utopia artística coincidisse com a realidade do mercado. A força da tropicália se baseia na transformação de contradições em simultaneidades. O que é poético, mas não é a prática capitalista. ${ }^{19}$

De outro ângulo, o "Manifesto" dos LPs Phono 73 não deixava de ser irônico. Em entrevista publicada em 1976, respondendo por que, além dos estudantes, "a alta burguesia" era "parte do seu público", Chico Buarque disse: "Não sei muito bem. Ela aceita e aplaude até as músicas que de certa forma a agridem, porque não se sente ameaçada" (BUARQUE, 1976, p. 301). Já em entrevista veiculada em 2005, Chico recordou tanto o "nível cotidiano da repressão", que instaurava um "clima de terror muito grande", quanto o apoio popular do chamado milagre econômico brasileiro e a "euforia incrível" de uma classe média que, "no tempo do Médici", viajava para a Argentina, que "ainda era uma democracia", onde se fartava nas churrascarias e cantava "aquelas músicas ufanistas, etc. e tal". Numa síntese afiada de Chico, algumas dessas famílias de classe média experimentavam uma "mistureba muito grande": "dinheiro no bolso" e um familiar que havia desaparecido (BUARQUE, 2005).

então desprezado, e a MPB, o novo produto. Foi assim que a história da música brasileira veio a conhecer tanto Clementina de Jesus como Edu Lobo". Após citar três espetáculos (O samba pede passagem, Arena conta Bahia e Liberdade, liberdade) e os festivais televisivos, Iná Camargo Costa retoma a crítica de Walter Benjamin "à tendência literária alemã chamada "nova objetividade", crítica apresentada por Benjamin no ensaio "Melancolia de esquerda. A propósito do novo livro de poemas de Erich Kästner"; e conclui: "Na esteira dos seus antepassados alemães dos anos 30, durante a ressaca que se seguiu ao golpe de 1964, nossos jovens artistas de esquerda renovaram a proeza de transformar a luta (passada) em mercadoria a ser consumida como seu sucedânea (no presente)" (COSTA, 1996, p. 111-112).

${ }^{19}$ Para uma crítica da relação entre a perspectiva política liberal de Caetano Veloso e as perspectivas políticas requeridas por sua prática musical, com conclusões diversas das que aqui apresento, ver BROWN (2014). 
Vê-se que a crítica de "Cálice”, em 1973, estava longe de ser compartilhada pela sociedade civil e, de modo mais específico, pelas classes médias brasileiras sem que várias tensões estivessem presentes. Três observações merecem ser feitas, desdobrando-se o que se examina. Em primeiro lugar, conforme ponderou Renato Ortiz acerca da questão da Censura, “os interesses globais dos empresários da cultura e do Estado [eram] os mesmos, mas topicamente eles [podiam] diferir". Assim, é preciso refletir sobre a concordância possível que houve entre "a ideologia da Segurança Nacional [que era] 'moralista' e a dos empresários, [que era] mercadológica", tendo-se em conta "que a indústria cultural opera segundo um padrão de despolitização dos conteúdos" (ORTIZ, 2001, p. 119).

Em segundo lugar, a "reorientação econômica" empreendida pelo Estado após 1964, "paralelamente ao crescimento do parque industrial e do mercado interno de bens materiais", fortaleceu "o parque industrial de produção de cultura e o mercado de bens culturais" (ORTIZ, 2001, p. 114). Nesse quadro é que se deu, ao longo da década de 1970, a grande expansão da indústria fonográfica no Brasil e a consolidação do seu processo de racionalização, fenômeno muito bem estudado por Marcia Tosta Dias (2008).

Em terceiro lugar, de fato o chamado milagre econômico intensificou as disparidades da "estrutura complexa" de classes sociais no Brasil: um dos efeitos do milagre foi tornar as "desigualdades entranhadas" de uma "pirâmide social cheia de distorções" em desigualdades "extremadas". Porém, entre o topo e a base, "havia camadas de amortecimento, e a sua existência conferiu saúde, estabilidade e vigor àquele corpo" (REIS FILHO, 2014, p. 91-92). ${ }^{20}$ Daniel Aarão Reis Filho observa que para a estabilidade da ditadura militar contribuíam, no começo da década de 1970, consideráveis apoios civis "ativos e conscientes", "a simpatia não entusiasta, a neutralidade benévola, a indiferença ou, no limite, a sensação de absoluta impotência", além de "atitudes ambíguas ou ambivalentes" (REIS FILHO, 2014, p. 83-84).

\footnotetext{
${ }^{20}$ Não se deve esquecer que o primeiro choque do petróleo, que contribui para a derrocada do chamado milagre econômico brasileiro, se deu em outubro de 1973, portanto meses após o Phono 73. Sobre os efeitos da crise mundial do petróleo no mercado fonográfico brasileiro, ver DIAS (2008, p. 58$59)$.
} 
Na verdade, "Manifesto" era claramente um texto publicitário que vendia o seu peixe. Em frases como "Nós aceitamos todas [as músicas] porque negá-las seria negar comunidades inteiras, com suas necessidades e suas formas de expressão. Estamos abertos à música que se faz no Brasil", escondiam-se (novamente) as peneiras da gravadora, voltadas fundamentalmente para o lucro. E em "Canto aberto. Pra todos que quiserem ouvir", escamoteava-se quem seriam "todos": o público consumidor. Na contracapa dos LPs, “O canto de um povo" celebrava o encontro entre a Companhia Brasileira de Discos Phonogram, uma divisão da empresa multinacional Philips, e os seus compradores.

\section{8, "disco da samambaia"}

“Cálice” permaneceu censurada de 1973 a 1978. Durante esse período, tal como outras canções proibidas, eventualmente era apresentada "em shows para estudantes" quando se percebia, segundo Chico Buarque, "que mais ou menos 'tava liberado (...). Tinha sempre muita gente gravando (...), então apareciam umas fitas piratas" (BUARQUE, 2005). Uma dessas fitas alcançou certa notoriedade entre estudantes da USP: a gravação do show de Gilberto Gil organizado pelo CCA (Conselho de Centros Acadêmicos) da USP e pelo Grêmio Politécnico em 26 de maio de 1973, no Biênio da Póli, sem pagamento de cachê ao artista e com entrada gratuita; no show, "Cálice" foi cantada duas vezes (COSTA, 2003).21

\footnotetext{
${ }^{21}$ Em 1985, quando ingressei como estudante na USP, fitas cassete desse show de Gilberto Gil ainda circulavam na Cidade Universitária. No momento em que escrevo, o show pode ser ouvido no YouTube. Ver Referências sonoras e audiovisuais, ao final do artigo. Não é o caso de desenvolver o ponto, mas vale registrar que, para aprofundar o entendimento da obra de Gil durante a década de 1970, a relação entre o cancionista e a plateia no Biênio da Póli, recordada como "um bálsamo de cumplicidade" na reportagem jornalística de Caio Túlio COSTA (2003, p. 262), deve ser cotejada com as tensões de outro show para estudantes na cidade de São Paulo, realizado no colégio Equipe em 1977. Segundo entrevista de Gilberto Gil naquela época: “Alguns tentaram abrir uma discussão aberta no meio do show comigo, uma discussão política a fim de exigir de mim posições em relação ao movimento estudantil, à repressão do sistema, à ineficácia dos planos econômicos do governo, um bocado de coisas que eu não estava ali para isso. Coisas que eu não me sentia na obrigação de responder porque eu tinha ido ali cantar, quer dizer, zelar pelo mito da arte, do exercício dessa arte. Essa é que era a minha função ali e tentei mostra isso". No dia seguinte ao show no Equipe, ainda segundo Gil, a sua tentativa de "levar o público a cantar as músicas", numa reprodução de "atmosfera ritualística" - "o dado religioso que é exatamente uma coisa que eu persigo, que eu gosto, que eu busco" - foi identificado por alguns jornalistas "como nazismo" (BAHIANA, 2006, p. 90-93).
} 
Liberada pela Censura em 1978, em meio ao processo de distensão lenta, gradativa e segura conduzido por Ernesto Geisel (presidente de 15/3/1974 a 15/3/1979), a composição de Gil e Chico foi gravada por Chico e Milton Nascimento, com participação do MPB4 e arranjo e regência de Magro, para o disco Chico Buarque - "o disco da samambaia", como é chamado informalmente por causa da foto na capa. Milton cantou as estrofes que haviam sido compostas por Gil (GIL, 2003, p. 139). Entre parênteses, é sintomático que pesquisadores como Adélia Bezerra de Meneses (2000, p. 91-92) e Gilberto de Carvalho (1982, p. 56-57) tenham atribuído a Chico Buarque algumas passagens da letra que, na realidade, foram compostas por Gilberto Gil: "Cálice” permaneceu, até o momento, vinculada ou à obra de apenas um de seus compositores ou às obras de Chico e de Milton (ambos seriam referidos por Criolo em 2010).

Em entrevista veiculada naquele ano de 1978, Chico Buarque advertiu que a liberação de algumas músicas vendia "a ideia e a imagem de uma abertura democrática entre aspas"; mas essa publicidade, para ele, nem deveria despertar gratidão, nem deveria ser recebida sem desconfiança, fosse porque havia "muita coisa pra ser liberada", fosse porque não se tinha a garantia de que as coisas não pudessem retornar ao estado anterior (BUARQUE, 2005). No ano seguinte, "Cálice", mesmo tendo "a sua mensagem enfraquecida" por estar "fora de seu tempo" (ou justamente por estar fora de seu tempo e ter a sua mensagem enfraquecida?), "bateu recordes de execução em estações de rádio e emissoras de TV em todo o país". Fato que exemplifica, na observação de Marcia Tosta Dias, que, "se a interferência da censura foi drástica do ponto de vista da criação artística, economicamente, a indústria do disco parece não ter sentido os seus efeitos" (DIAS, 2008, p. 62). Nessa gravação, a forma musical da canção é: introdução vocal, A, A, B, B, A, B, B, A, parte instrumental, B, B, A, B, B.

A introdução vocal estiliza um canto litúrgico, preparando o ouvinte para o célebre refrão (parte A), que será entoado duas vezes. A construção melódica do refrão se baseia na variação da primeira frase. Cantado três vezes, o verso "Pai, afasta de mim esse cálice" tem a expressão de súplica e o efeito de sofrimento intensificados pelo modo como se organizam as três primeiras frases musicais, ou seja, pelo 
movimento ascendente que altera as notas iniciais/finais das frases (Sol\#; Lá; Si) e as notas do salto de $8^{\mathrm{a}}$ (Si - Si; Dó - Dó; Dó\# - Dó\#). Já a quarta frase, com a qual se entoa "De vinho tinto de sangue", de certa maneira se contrapõe às anteriores: sem deixar de ser uma nova variação da primeira frase, nela o salto passou a ser de $7^{\text {a }}$ menor (Si - Lá) e os graus conjuntos conduzem para o repouso na tônica (Mi), movimento que soa confortável. Assim, a frase musical sugere um apaziguamento incompatível com a imagem cantada (sinal de via mística ou marca de oportunidade comercial?). Entretanto o verso é cantado com amargura por Chico Buarque e, sobretudo, por Milton Nascimento, e a performance vocal resolve um problema da composição (nas vezes seguintes, a emissão dessa frase em coro imprimirá indignação ao verso, além de amargura).

Pai, afasta de mim esse cálice

Pai, afasta de mim esse cálice

Pai, afasta de mim esse cálice

De vinho tinto de sangue

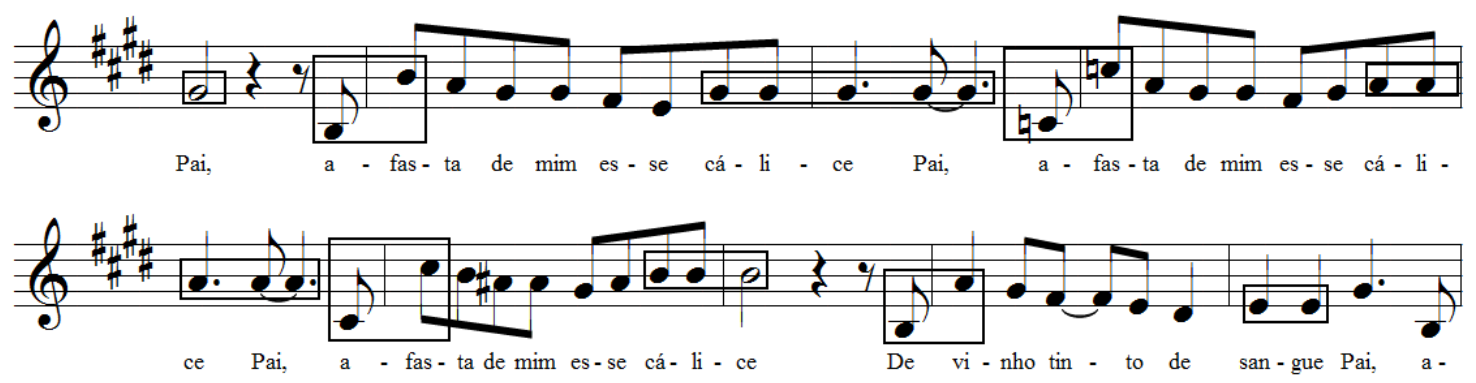

Ex.3 - Parte A de "Cálice" (Gilberto Gil/ Chico Buarque), com saltos de $8^{a}$ e notas inicias/finais das frases em destaque.

Com isso, os 57 segundos iniciais do fonograma instalam o sofrimento, a súplica e a monotonia da prece. Esse caráter atravessará toda a canção. A monotonia será confirmada pela estrutura da parte B, formada por quatro frases melódicas bastante semelhantes entre si: a segunda, a terceira e a quarta são variações da 
primeira frase 22 (como se percebe, o mesmo recurso de composição utilizado na melodia da parte A).

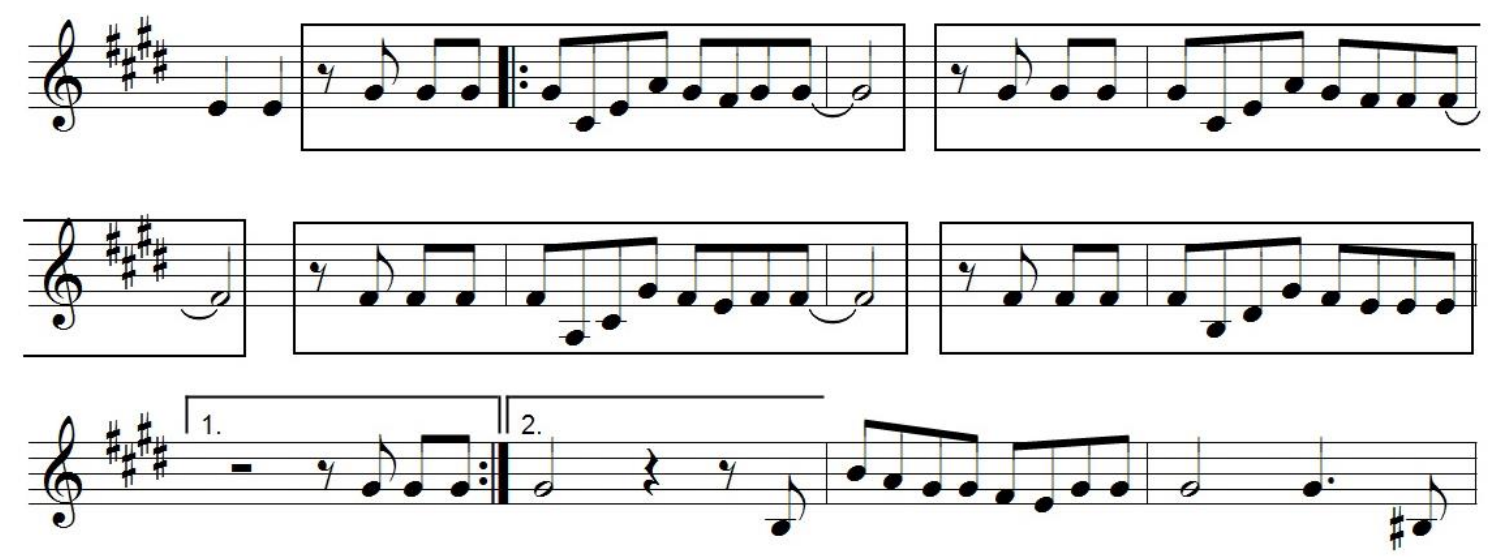

Ex.4 - Parte B de "Cálice" (Gilberto Gil/ Chico Buarque), com as quatro frases melódicas em destaque.

Com base nessa construção melódica, a letra da parte B se organizará em quadras com versos decassílabos. ${ }^{23}$ Todavia nem os contornos melódicos nem o metro fixo determinaram aos compositores apenas uma cadência (entendendo-se por "cadência" o ritmo do verso que resulta da alternância de sílabas tônicas e átonas). Nesse sentido, e talvez nem fosse preciso dizer, a partitura acima segue a regra da escrita da canção popular: resulta de uma simplificação rítmica da melodia. Na prática, Milton Nascimento e de Chico Buarque entoam as frases melódicas de acordo com a acentuação que os versos teriam se declamados (exceção feita a alguns poucos casos), seja porque algumas notas são atacadas com maior intensidade, seja porque algumas notas aumentam de duração.

\footnotetext{
${ }^{22}$ Não custa ressaltar que a transposição um tom abaixo da primeira frase melódica gera a terceira frase, havendo contudo a adaptação de duas notas (cantam-se Lá e Dó\# em lugar de Si e Ré\#, notas que manteriam os mesmos intervalos da primeira frase).

${ }^{23}$ Ao comentar "Cálice", Gilberto Gil disse que as estrofes da letra são quatro, duas compostas por ele (a primeira e a terceira), duas por Chico Buarque (a segunda e a quarta), cada qual com oito decassílabos (GIL, 2003, p. 139). Não é o que a análise da canção confirma, seja pela estrutura musical da parte $\mathrm{B}$, seja pela disposição das rimas, seja porque as quadras não apresentam um encadeamento linear entre si. Sobre o último ponto, Gilberto Gil afirma o mesmo sobre as estrofes "em oito decassílabos". Experimente-se alterar a ordem das quadras (mantendo-se apenas a última quadra que se canta originalmente no seu lugar; e cuidando-se para que não se perca a sequência "Mesmo calada a boca, resta o peito", "Mesmo calado o peito, resta a cuca") e veja-se como a letra não sairá prejudicada.
} 
Tomando por base o estudo de M. Cavalcanti Proença (1955) sobre as possibilidades de segmentação rítmica dos versos decassílabos, temos as seguintes acentuações na gravação de "Cálice" (nos limites desta análise, não é preciso distinguir entre acentos principais e secundários, salvo observações pontuais nas notas de rodapé):

\section{[Milton Nascimento]}

Como beber dessa bebida amarga (4-8-10)

Tragar a dor, engolir a labuta (4-7-10)24

Mesmo calada a boca, esta o peito (4-6-8-10)

Silêncio na cidade não se escuta (2-4-6-8-10)25

De que me vale ser filho da santa (4-6-7-10)

Melhor seria ser filho da outra (4-6-7-10)26

Outra realidade menos morta (1-4-8-10)

Tanta mentira, tanta força bruta (1-4-6-8-10) ${ }^{27}$

(refrão)

\section{[Chico Buarque]}

Como é difícil acordar calado (4-8-10)

${ }^{24} \mathrm{Em}$ "Como beber dessa bebida amarga/ Tragar a dor, engolir a labuta", Milton Nascimento prolonga a última vogal dos versos ("amarga" e "labutạ"). Não considero todavia que o recurso, utilizado ostensivamente para exprimir sofrimento, prejudique a prosódia. Fato semelhante ocorrerá em "Outra realidade menos morta".

${ }^{25}$ Se declamado, o verso seria um decassílabo heroico, com cesura na $6^{a}$ sílaba: "Silêncio na cidade não se escuta". Porém, o canto de Milton Nascimento sugere o decassílabo sáfico com a divisão 4-8: "Silêncio na cidade não se escuta". Fato semelhante ocorrerá em "Outra realidade menos morta", cantado por Milton Nascimento com a acentuação "Outra realidade menos morta" (1-4-8-10). E também em "Ver emergir o monstro da lagoa" (4-6-8-10): Chico Buarque acentuará da (tornado acento

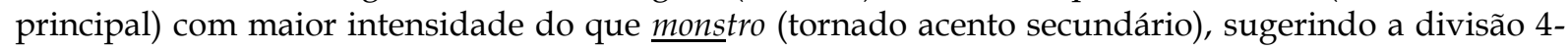
8-10, característica do decassílabo sáfico.

${ }^{26}$ Nos versos "De que me vale ser filho da santa/ Melhor seria ser filho da outra", a colisão de "duas sílabas fortes de vocábulos diferentes" determina que a declamação atenue "a intensidade da primeira" sílaba, isto é, que a palavra ser tenha "valor de sílaba fraca" (PROENÇA, 1955, p. 28). Milton Nascimento todavia canta prolongando a palavra ser. O resultado é que os dois versos são cantados como versos duros, isto é, como versos em que colidem duas sílabas tônicas. Adiante na canção, os versos "Quero inventar o meu próprio pecado (4-7-10)", "Quero morrer do meu próprio veneno (4-710)", "Quero perder de vez tua cabeça (4-6-8-10)", todos cantados por Chico Buarque, também poderiam ser entoados como versos duros, o que não ocorre.

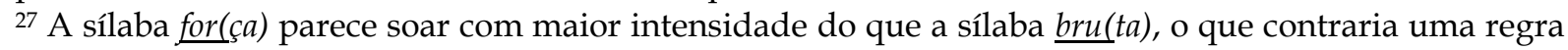
básica de acentuação dos versos. 
Se na calada da noite eu me dano (4-7-10)

Quero lançar um grito desumano (4-6-10)

Que é uma maneira de ser escutądo (4-7-10)

Esse silêncio todo me atordoa (4-6-10)

Atordoạdo eu permaneço atento (4-8-10)

$\mathrm{Na}$ arquibancada pra a qualquer momento (4-8-10)

Ver emergir o monstro da lagoa (4-6-8-10)

(refrão; parte instrumental)

\section{[Milton Nascimento]}

De muito gorda a porca já não anda (4-6-8-10) [Coro] Cale-se!

De muito usada a faca já não corta (4-6-8-10)

Como é difícil, Pai, abrir a porta (4-6-10) [Coro] Pai! Cale-se!

Essa palavra presa na garganta (4-6-10)

Esse pileque homérico no mundo (4-6-10)

De que adianta ter boa vontade (4-6-10)

Mesmo calado o peito, resta a cuca (4-6-8-10)

Dos bêbados do centro da cidade (2-6-10)

(refrão)

\section{[Chico Buarque]}

Talvez o mundo não seja pequeno (4-7-10) [Coro] Cale-se!

Nem seja a vida um fato consumado (4-6-10) [Coro] Cale-se, cale-se!

Quero inventar o meu próprio pecado (4-7-10) [Coro] Cale-se, cale-se, cale-se!

Quero morrer do meu próprio veneno (4-7-10) [Coro] Pai! Cale-se, cale-se, cale-se!

Quero perder de vez tua cabeça (4-6-8-10) [Coro] Cale-se!

Minha cabeça perder teu juízo (4-8-10) ${ }^{28}$ [Coro] Cale-se!

Quero cheirar fumaça de óleo diesel (4-6-8-10) [Coro] Cale-se!

Me embriagar até que alguém me esqueça (4-6-8-10) [Coro] Cale-se!

${ }^{28}$ Se declamado, “Minha cabeça perder teu juízo" seria um verso provençal, com segmentação "Minha cabeça perder teu juízo" (4-7-10). Já "Quero cheirar fumaça de óleo diesel (4-6-8-10), se declamado, seria um decassílabo heroico, com cesura na $6^{a}$ sílaba. Nos dois casos, Chico Buarque entoa os versos como decassílabos sáficos. 
Dizendo de outro modo e ampliando o que se diz: Milton e Chico cantam declamando os versos e não só respeitam a prosódia como valorizam as imagens desconcertantes da letra, ${ }^{29}$ expressando, assim, emoções e críticas sobre a tortura física e a tortura espiritual aplicadas pelos aparelhos repressivos do Estado, bem como sobre o castigo espiritual infligido pelo arbítrio da Censura Federal. Deve-se ter em conta a função do "trabalho sujo e degradante da tortura" na sustentação do regime autoritário:

Nas pesquisas realizadas sobre os aparelhos de repressão, está mais do que demonstrada a ligação direta - e a simbiose - entre os "órgãos" de informação e os ministros de Estado, em contato direto com a Presidência da República. Carecem de sentido, e de evidências, as suposições de que os aparelhos de segurança funcionassem de modo autônomo, sem controle ou respeito pela linha de comando. É nesse preciso sentido que se pode falar da tortura como "política de Estado" (REIS FILHO, 2014, p. 102).

Finalizando a análise, vejamos outros recursos por que "Cálice" exprime afetos e pensamentos. Ao longo da canção, o andamento desacelerado contribuirá para o efeito de prece lamentosa e monótona construído não só pela letra em si mas, sobretudo, pelo modo como a letra é cantada no refrão (entoado cinco vezes) e na parte B (executada oito vezes). Esses recursos condensam, de forma mais intensa, a experiência histórica de sofrimento causado por uma situação de censura e de tortura, situação aparentemente sem saída cujo limite aponta para a morte - ou para o assassinato - dos sujeitos da canção. Daí soarem perfeitamente verossímeis, no todo de "Cálice/Cale-se", 30 a identificação com a paixão de Cristo e a súplica ao Pai, concorde-se ou não com o apelo à dimensão religiosa.

${ }_{29}$ Como já foi amplamente estudado, a utilização de imagens poéticas foi uma das estratégias utilizadas por diversos cancionistas para tentar driblar a Censura durante a década de 1970.

${ }^{30}$ Embora a fórmula "Cálice/Cale-se" decorra da própria composição, que ostensivamente utiliza a paronomásia, é preciso dizer que, salvo desconhecimento meu, Adélia Bezerra de MENESES (2000, p. 91) foi quem primeiro sintetizou desse modo o tema de "Cálice" (o trabalho foi apresentado em 1981 como tese de doutoramento em Teoria Literária e Literatura Comparada à FFLCH-USP). No entanto, para Meneses, essa síntese é o primeiro nível de leitura, "uma decodificação político-social do poema [que] se impõe, e é cristalina: trata-se do silêncio imposto, da Censura do governo Médici (o poema é de 1973) que silencia a voz do poeta. Mas não apenas ela: o arbítrio da repressão silencia - no limite, com o silêncio definitivo da morte - todos aqueles que ousassem falar" (MENESES, 2000, p. 92). A seguir, notando "algumas imagens desnorteadoras, que resistem a uma interpretação histórica", Meneses propõe uma decodificação do "nível mítico" do texto (MENESES, 2000, p. 93-98). E, no meu entendimento, o seu trabalho se enfraquece bastante. A princípio, nada tenho contra interpretações de 
De outro lado, conforme se argumentou, a variação nas acentuações dos versos decassílabos condensa a experiência histórica de revolta e de crítica dos sujeitos da canção. Trata-se de um recurso sutil, coerente com a resistência política abafada. Junto dele, outros recursos quebrarão a monotonia e sintetizarão a crítica e a revolta de maneira mais evidente: as imagens da letra; o encadeamento não linear das estrofes; o esquema de rimas; o canto dividido por dois intérpretes; a gravação de voz dobrada na última estrofe (por Chico Buarque); a atuação do coro na parte A (na parte B, salvo um único "Pai!", o coro encarnará o arbítrio da repressão); o arranjo instrumental.

\section{0, Criolo Doido - Cálice}

Um improviso em meio a uma situação cotidiana, encenado de forma simples e eficiente: num dia qualquer, enquanto escolhe o que comer, o que beber, o que consumir, Criolo entoa a capella (sem acompanhamento instrumental) versos "explicitando a herança da ditadura na insegurança das ruas e na manutenção das desigualdades, atualizando uma canção emblemática do protesto contra o regime militar" (VILLAÇA, 24 mai. 2014). Junto da performance do rapper, outros elementos constroem a verossimilhança. Há o tempo do vídeo (1:26) e, obviamente, há a locação. Mas também há os movimentos de câmera, que se limitam a nos aproximar um pouco mais, um pouco menos do rosto de Criolo, a girar lentamente para a direita ou para a esquerda: mostrando Criolo Doido do peito para cima (ou seja, em primeiro plano), o enquadramento nos apresenta a lanchonete por metonímia, reforçando o caráter circunstancial do lugar e da situação. De fato, o balcão é percebido sem que seja mostrado. Vê-se mais a aba do boné do que o perfil do funcionário que serve o rapper, funcionário para quem alguns versos são dirigidos. E

cunho religioso. Mas é estranho que Meneses não tenha percebido que os versos "cálice/ de vinho tinto de sangue", "morrer do próprio veneno", "inventar o próprio pecado", "esse pileque homérico no mundo" (MENESES, 2000, p. 93) apresentam imagens mais ou menos cristalinas de uma situação histórica em que os torturadores fazem os torturados sangrarem, em que a resistência impõe a criação de políticas que serão silenciadas, no limite, com o assassinato dos que resistem, e em que boa parte da sociedade brasileira, como se estivesse embriagada, ou é simpática ou é neutra ou é indiferente ou é ambígua ou é ambivalente ou se sente impotente para reagir a tudo isso. 
vê-se a aba do boné muito rapidamente, de tal modo que adivinhar a palavra "Lanchonete", acima do que parece ser o desenho de um x-salada, é tarefa para quem pausa o vídeo em 1:03 e afia os olhos.

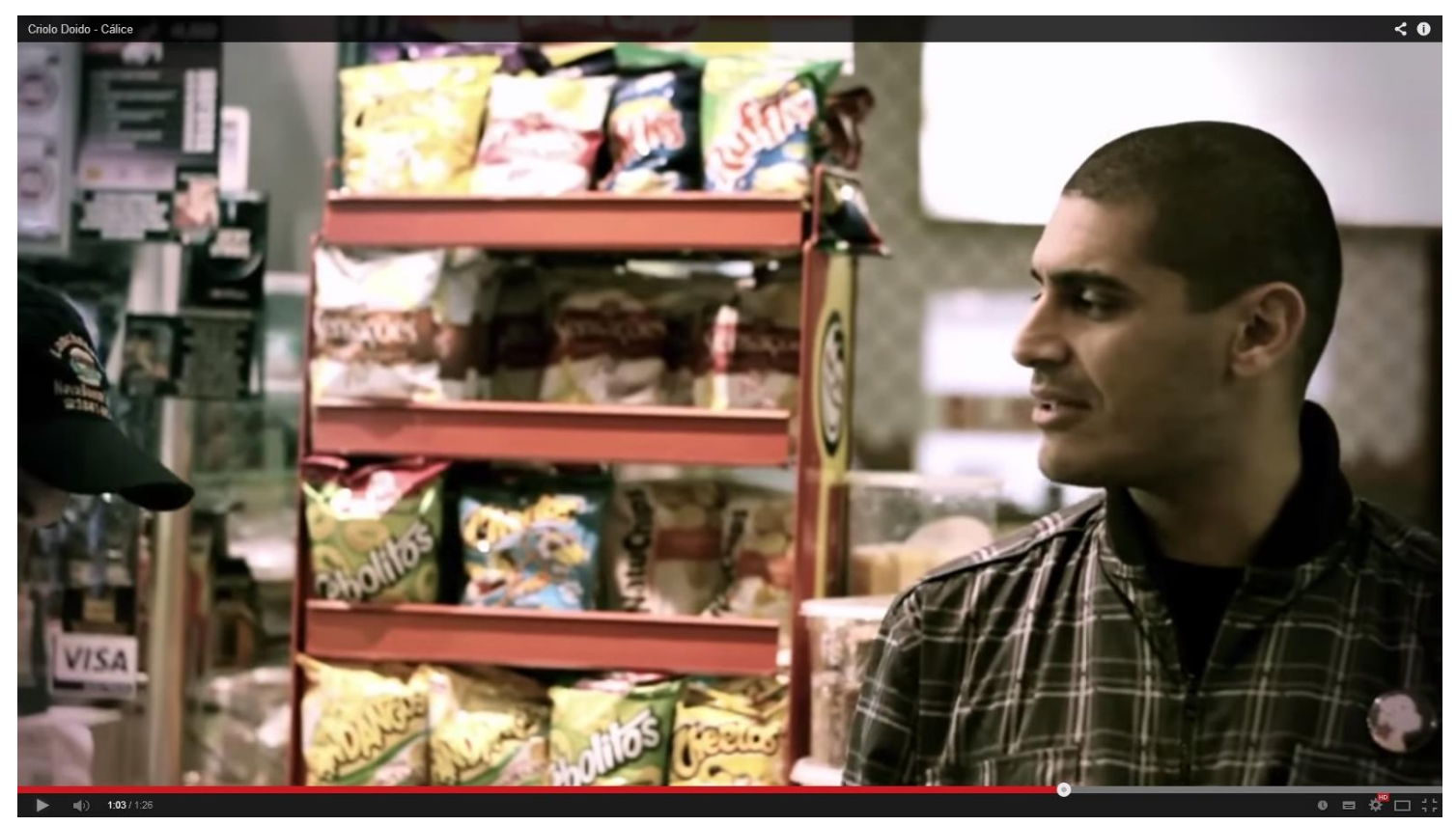

Ex.5 - Criolo Doido - Cálice, 1:03.

Ao ignorar o rapper, a atuação desse funcionário também contribui para a aparência de improviso. É como se assistíssemos a imagens captadas em um celular. Imagens casuais, afins com versos improvisados, afins com a veiculação no YouTube. ${ }^{31} \mathrm{E}$ os ruídos do trânsito, que escutamos e que sabemos de onde principalmente vêm, pois enxergamos a porta do estabelecimento aberta para a rua, os ruídos do trânsito também contribuem para o efeito de improvisação.

O vídeo Criolo Doido - Cálice, difundido no YouTube a partir de setembro de 2010, condensa alguns dados da formação poética e musical do rapper. E parte da força do vídeo decorre dessa condensação, pois se recriam e se potencializam experiências não só de Kleber Cavalcante Gomes (Criolo), mas de um grande número de jovens que habitam nas periferias das grandes cidades brasileiras: a) no âmbito da

\footnotetext{
${ }^{31}$ Quem me chamou a atenção para a afinidade entre o vídeo aparentemente improvisado de Criolo e a aparente casualidade de muitos e muitos vídeos difundidos no YouTube foi Renato Gonçalves Ferreira Filho.
} 
cultura Hip Hop, as batalhas de freestyle, eventos em que MCs duelam improvisando versos; 32 b) ainda no âmbito do Hip Hop, a "ideia da veracidade, do seja você mesmo" (PIMENTEL, 2007, p. 119);33 tal ideia leva à expressão musicada da dor (NOGUEIRA, 23 set. 2011), bem como do pensamento sobre "a sua realidade em sua cidade", tendo o rapper vivido, desde cedo, "em um ambiente extremamente hostil, no extremo sul da Zona Sul de São Paulo" (PRETO, 2013, p. 10-11); c) a recitação de poemas e de letras de canções nos saraus literários, eventos que têm como marco inicial os encontros da Cooperifa, desde outubro de 2001, e que, aumentando de número "em todas as regiões de São Paulo" e publicando coletâneas, se constituem num amplo espaço de desenvolvimento e de consolidação da Literatura Periférica a partir de 2005 (LEITE, 2014); d) a MPB que, desde criança, Kleber ouviu cantarolada por “seus pais e vizinhos” (NISHIMURA, 2013, p. 21).

Já se notou que Criolo “canta outra letra, sobre a mesma melodia, sem respeitar muito a métrica" (BRAZIL, 21 jul. 2011). Vejamos como o rapper trabalha com liberdade sobre a base de Gil, Chico e Milton. A forma musical da improvisação é: B, B, B, B, A, A. Entoado a capella, o canto não se orienta pela métrica do compasso quaternário: as frases musicais se orientam por rítmica discursiva. E os versos da parte B não possuem todos o mesmo metro, embora se perceba que a variedade não seja muito ampla: cinco versos são decassílabos; seis versos têm 11 sílabas; e cinco versos têm entre 12 e 15 sílabas. Esses recursos indicam que a transposição direta da realidade se dá mais pelo pensamento do que pela musicalidade. Mas podemos

32 Em 2006, ano em que lançou o seu primeiro CD, Ainda há tempo, Criolo fundou, ao lado do DJ DanDan, a Rinha dos MC's. Sobre o assunto, ver <http://rinhadosmcs.com.br>. Sobre freestyle, modalidade de improviso entre rappers, ver TEPERMAN (2011).

${ }^{33}$ A observação é de GOG quando, em entrevista, respondeu sobre os vínculos que a poesia do rap brasileiro mantém com a história pessoal e o comportamento dos rappers. A fim de que se compreenda melhor a citação, transcrevo outras passagens: "O rap te dá a oportunidade de falar em primeira pessoa, você se assume ali, é como se você se personificasse, como se você realmente pudesse ser você, com autoridade de ser você, em cima do palco, com as pessoas te ouvindo. É nesse momento que você vai exercer o seu direito de falar: olha, é isso, isso, isso, acredito nisso, não acredito naquilo. $\mathrm{E}$ é nesse momento também que você tem que ter a estrutura para falar, mesmo diante de todo o seu problema, o que realmente causou aquilo. (...) Embora periferia seja periferia em qualquer lugar, as experiências, por mais parecidas, não são as mesmas. (...) É isso que o Hip Hop tem como contribuição: essa primeira pessoa tanto no discurso como no sofrimento, na passagem realmente por aquilo ali. (...) Não precisa você vestir um personagem, ser ele duas horas do show e passar as outras 22 horas se escondendo daquele personagem" (PIMENTEL, 2007, p. 118-119 e 121). Saliente-se que GOG não afirmou que um rapper não se trata de um personagem, mas sim que se trata de um personagem que reconta as experiências do sujeito e que reflete sobre elas. Daí "a ideia da veracidade, do seja você mesmo". 
afirmar o contrário, que a recriação do cotidiano se dá mais pela musicalidade do que pelo pensamento, em virtude das ostensivas repetições de palavras: ao final dos dois primeiros versos (epífora); ao início de todos os versos da terceira estrofe (anáfora); na estrutura dos dois primeiros versos da quarta estrofe (encadeamento). E a estrutura do refrão é marcada pela reiteração. Em síntese, pensamento e musicalidade se equilibram na recriação e na crítica da realidade cotidiana.

As estrofes de Criolo desembocam no refrão, o que significa dizer que o relato e a crítica desembocam na prece. No vídeo, o olhar de Criolo se dirige ao alto quando o refrão é repetido, reforçando o efeito. Mas o refrão do rapper não só sintetiza o sofrimento como também prolonga o relato e a crítica de uma situação sócio-histórica - note-se que o refrão de Gilberto Gil e de Chico Buarque, o qual fundamentalmente estilizava uma prece, também relatava e criticava a situação de censura ("cale-se") e de tortura ("De vinho tinto de sangue"). Na primeira estrofe e no refrão de Criolo, são empregadas gírias, e assim a crônica se forma com a linguagem oral dos lugares e dos confrontos narrados: fritar, consumir crack; brisa, efeito provocado pelo consumo de entorpecentes; biqueira, local onde há comércio de drogas ilícitas; biate, adaptação do inglês bitch. ${ }^{34}$

Como ir pro trabalho sem levar um tiro

Voltar pra casa sem levar um tiro

\begin{abstract}
${ }^{34}$ Agradeço a Antonio Eleilson Leite e a Guilherme Botelho as conversas informais, por e-mail, sobre o vídeo Criolo Doido - Cálice. Ambos me auxiliaram no entendimento das gírias e, portanto, o mérito do acerto é deles, sendo exclusivamente minha a responsabilidade por qualquer equívoco. Sobre biate, Guilherme Botelho escreveu em 4/6/2014: “Os cantores de rap estadunidenses já utilizavam biate na gíria do inglês falado pelos niggaz. Dr. Dre, por exemplo, tem uma música que começa com a palavra, 'Let me ride'; ver <http://www.youtube.com/watch?v=RgWDzLIF654>. Muitos MCs de São Paulo utilizaram o termo, tanto na forma da gíria americana, como o Criolo, quanto na forma 'tradicional', bitch. Em 1992, saiu uma coletânea chamada Vozes de Rua. Um dos grupos participantes era o Doctors MC's, e a música se chamava 'Garota Sem Vergonha (Bitch)'; ver <http://www.youtube.com/watch?v=Q_F-PfopiSo>". Antonio Eleilson Leite, em 5/6/2014, escreveu-me depois de conversar com Criolo. Disse-me que Criolo afirmara que o gesto que faz no vídeo, entre a segunda e a terceira estrofe, não é para pedir nem café, nem cachaça, mas para pedir "misericórdia". Eleilson Leite ainda acrescentou: "Lembro-me bem quando esse vídeo foi gravado; assisti em primeira mão. Criolo gravou no Rio de Janeiro em setembro de 2010. Ele estava lá integrando a comitiva de artistas periféricos de São Paulo no Encontro da Diversidade Cultural, promovido pelo MinC. Eu mesmo fui o responsável por organizar essa comitiva para o ministério e o inclui num grupo de 25 artistas. Alguns dias depois de seu retorno [a São Paulo], Criolo me chamou aqui no terceiro andar da nossa sede [da Ação Educativa], onde ficava o Centro de Mídia Juvenil. Ele era usuário dos computadores ali disponíveis. Mostrou-me entusiasmado a versão que fez para a canção do Chico e do Gil. Até onde eu sei, não foi uma gravação de celular, não".
\end{abstract}


Se às três da matina tem alguém que frita

E é capaz de tudo pra manter sua brisa

$\mathrm{Co} / \mathrm{mo} \mathrm{ir} / \mathrm{pro} / \mathrm{tra} / \mathrm{ba} / \mathrm{lho} / \mathrm{sem} / \mathrm{le} / \mathrm{var} / \mathrm{um} / \mathrm{ti} / \mathrm{ro}$ (11 sílabas)

Vol/tar/ pra/ ca/sa/ sem/ le/var/ um/ ti/ro (10 sílabas)

Se às/ três/ da/ ma/ti/na/ tem/ al/guém/ que/ fri/ta (11 sílabas)

E é/ ca/paz/ de/ tu/do/ pra/ man/ter/ sua/ bri/sa (11 sílabas)

Os saraus tiveram que invadir os botecos

Pois biblioteca não era lugar de poesia

Biblioteca tinha que ter silêncio

E uma gente que se acha assim muito sabida

Os/ sa/raus/ ti/ve/ram/ que in/va/di' os/ bo/te/cos (11 sílabas)

Pois/ bi/blio/te/ca/ não/ e/ra/ lu/gar/ de/ po/e/sia (14 sílabas)

$\mathrm{Bi} / \mathrm{blio} / \mathrm{te} / \mathrm{ca} / \mathrm{ti} / \mathrm{nha} / \mathrm{que} / \mathrm{ter} / \mathrm{si} /$ lên/cio (10 sílabas)

$\mathrm{E} \mathrm{u/ma/gen/te/} \mathrm{que/} \mathrm{se/} \mathrm{a/cha} \mathrm{a/ssim/} \mathrm{mui/to/sa/bi/da} \mathrm{(13} \mathrm{sílabas)}$

Há preconceito com o nordestino

Há preconceito com o homem negro

Há preconceito com o analfabeto

Mas não há preconceito se um dos três for rico, Pai

Há/ pre/con/cei/to/ com/ o/ nor/des/ti/no (10 sílabas)

Há/ pre/con/cei/to/ com/ o/ ho/mem/ ne/gro (10 sílabas)

Há/ pre/con/cei/to/ com/ o a/nal/fa/be/to (10 sílabas)

Mas/ não/ há/ pre/con/cei/to/ se um/ dos/ três/ for/ ri/co,/ Pai/ (13 sílabas)

A ditadura segue, meu amigo Milton

A repressão segue, meu amigo Chico

Me chamam Criolo, o meu berço é o rap

Mas não existe fronteira pra minha poesia, Pai

A/ di/ta/du/ra/ se/gue,/ meu/ a/mi/go/ Mil/ton (12 sílabas)

A/ re/pre/ssão/ se/gue,/ meu/ a/mi/go/ Chi/co (11 sílabas)

$\mathrm{Me} / \mathrm{cha} / \mathrm{mam} / \mathrm{Cri} / \mathrm{o} / \mathrm{lo}$ / o/ meu/ ber/ço é o/ rap/ (11 sílabas)

Mas/ não/ e/xis/te/ fron/tei/ra/ pra/ mi'a/ po/e/si/a/, Pai/ (15 sílabas) 
Afasta de mim a biqueira, Pai

Afasta de mim as biate, Pai

Afasta de mim a cocaine, Pai

Pois na quebrada escorre sangue, Pai

A/fas/ta/de/ mim/ a/ bi/quei/ra,/ Pai/ (10 sílabas)

A/fas/ta/ de/ mim/ as/bi/a/te,/ Pai/ (10 sílabas)

A/fas/ta/ de/ mim/ a/co/cai/ne,/ Pai/ (10 sílabas)

Pois/ na/ que/bra/da/ es/co/rre/ san/gue,/ Pai/ (11 sílabas)

Pai

Afasta de mim a biqueira, Pai

Afasta de mim as biate, Pai

Afasta de mim a cocaine, Pai

Pois na quebrada escorre sangue

A barbárie da violência retratada na primeira estrofe é contraposta, na segunda estrofe, ao esforço civilizatório (a expressão é de Maria Rita Kehl, referindo-se ao trabalho do Racionais MC's) dos saraus literários. Esforço civilizatório ao qual a cultura e a educação institucionalizadas respondem com a tentativa de impor o silêncio. Ampliando o quadro de exclusão, enumeram-se mais três alvos de preconceito e, com ironia, observa-se que nenhum deles é atingido caso esteja posicionado, por quais meios não se diz (o que é bastante significativo), no topo da pirâmide econômica. Na quarta estrofe, quando se dirige a Milton e a Chico, Criolo retoma tanto o título de outra canção de Chico Buarque, "Meu caro amigo" (em parceria com Francis Hime), quanto o título do seu LP de 1976, Meus caros amigos. Retoma, portanto, outra canção cuja letra aborda a censura e a repressão na década de 1970.

Criolo não se dirige aos dois artistas da chamada MPB nem com adulação, nem com menosprezo. Nem há propriamente confronto, mas há um aviso, quase uma chamada, pois se entende que a obra atual de Milton e a obra atual de Chico não falam do autoritarismo que prossegue. De fato, o poder de crítica da chamada MPB se enfraqueceu de tal modo, desde a década de 1980, que hoje parece que a sigla não 
tem nada a dizer sobre as várias formas de violência que atravessam a sociedade brasileira.

\section{1, show de Chico Buarque}

Entretanto, Criolo Doido - Cálice não deixa de assinalar um momento em que o rap legitimou a MPB como matéria-prima das culturas das periferias. Nessa perspectiva, o vídeo não deixa se ser uma homenagem de Criolo a Milton e a Chico. Foi a isso que Chico Buarque respondeu com "Rap de Cálice", composição que incluiu na sua turnê de 2011 e no DVD que dela resultou (BUARQUE, 2012). ${ }^{35}$

Gosto de ouvir o rap, o rap da rapaziada

Um dia vi uma parada assim no YouTube

E disse: “Que os pariu, parece o 'Cálice'

Aquela cantiga antiga minha e do Gil"

Era como se o camarada me dissesse:

"Bem-vindo ao clube, Chicão, bem-vindo ao clube"

Valeu, Criolo Doido, evoé, jovem artista

Palmas pro refrão doído do rapper paulista

Pai, afasta de mim a biqueira

Pai, afasta de mim as biate

Afasta de mim a cocaine

Pois na quebrada escorre sangue

Pai, afasta de mim esse cálice

Pai, afasta de mim esse cálice

Pai, afasta de mim esse cálice

De vinho tinto de sangue

Interessante que "o rap da rapaziada" seja referido a um clube, ou seja, a uma associação que não está aberta a qualquer um. Como se sabe, candidatos a

\footnotetext{
${ }^{35}$ Mais de uma gravação informal da apresentação de "Rap de Cálice", desde 2011, foi veiculada no YouTube. No momento em que escrevo, permanecem disponíveis para quem tem acesso à internet.
} 
frequentar um clube devem ser aceitos por seus sócios. Trata-se de uma situação nova para um dos principais artistas da chamada MPB, Música Popular Brasileira: Chico Buarque reconhece que precisou ser aceito em um lugar social que não é o dele, um lugar social onde se produz canções com alta elaboração estética. Por outro lado, jogando no seu próprio campo, Chico elegantemente retribui a homenagem, cita a sua composição "Paratodos" (BUARQUE, 1993) e legitima Criolo. Assim, a resposta de Chico Buarque constrói uma via de mão dupla.

É certo que a MPB vem caindo de cotação, o que não significa que tenha deixado de ser o principal selo de qualidade da canção popular brasileira. Não custa lembrar que, nos anos 2000, os novos CDs de Chico Buarque e os DVDs com registros de suas turnês passaram a ser lançados pela Biscoito Fino, não por uma das gigantes transnacionais (no momento em que escrevo, Sony Music Entertainment, Universal Music, Warner Music). Tenha sido ou não uma opção de Chico, de modo geral,

as transformações nas condições técnicas da produção têm favorecido a participação de pequenas gravadoras e selos independentes (indies), a ponto de atraírem atualmente - como se verifica no caso brasileiro - artistas que preferem trocar o conforto contratual das majors pela possibilidade de realizar trabalhos menos comprometidos com a lógica do mercado. (DIAS, 2008, p. 185-186).

Sobre essa lógica, o mínimo que se pode dizer é que hoje o mercado fonográfico hegemônico não esconde de ninguém que os seus objetivos se voltam fundamentalmente para o lucro. Escancaram-se a repetição sem limites de mais do mesmo 36 e o bombardeio de vermes sonoros. Tal como em outros ramos do negócio do entretenimento, as peneiras de cantores e cantoras se tornaram espetáculos glamorosos, justificados pela distribuição de prêmios e de humilhações, levando a outro patamar o velho show de calouros. E, se as pequenas gravadoras investem no marketing dirigido e em ações localizadas, as operações de marketing das grandes empresas de música gravada ainda "envolvem uma rede de parceiros e interesses que garantem exposição em espaços privilegiados da grande mídia (programas de rádio e de TV, novelas, publicidade etc.)" (DIAS, 2008, p. 186; 192). Na soma de tudo

\footnotetext{
${ }^{36}$ Marcia Tosta DIAS (2008, p. 186) anotou esses "títulos sugestivos, se não irônicos", de duas séries de coletâneas lançadas por majors: Sem limites (Universal Music) e Mais do mesmo (EMI).
} 
isso, ainda vale muito ser aceito no clube da MPB, sobretudo quando se é apresentado por Chico Buarque.

O que "Rap de Cálice" deixa de lado, porém, é a crônica da ditadura e da repressão atuais. A isso ou, em outras palavras, ao tema de Criolo Doido - Cálice, a composição de Chico não responde. ${ }^{37}$ No show da MPB, os versos de Criolo nem sintetizam sofrimento nem relatam ou criticam o cotidiano das periferias urbanas: os versos do "refrão doído" (repare-se no ótimo artesanato de Chico) são as ótimas referências de um "jovem artista".

\section{Referências bibliográficas}

\section{Livros}

A BÍBLIA DE JERUSALÉM. Ed. rev., 4. impressão. São Paulo: Paulinas, 1989.

ADORNO, Theodor W. Crítica cultural e sociedade. In: Prismas: crítica cultural e sociedade. Trad. A. Wernet; J. M. B. de Almeida. São Paulo: Ática, 1998, p. 7-26.

ARAÚJO, Paulo César de. Eu não sou cachorro, não: música popular cafona e ditadura militar. Rio de Janeiro: Record, 2002.

\footnotetext{
37 Stive Vicente Ferreira e Giovanni Santa Rosa, estudantes de graduação da USP, chamaram-me a atenção para essa diferença fundamental entre Criolo Doido - Cálice e "Rap de Cálice" em trabalhos de aproveitamento produzidos no $2^{\circ}$ semestre de 2014: “Chico nos apresenta a crônica de um cotidiano, o seu cotidiano, em oposição à crônica de Criolo, que nos fala de um cotidiano coletivo, pois há toda uma comunidade representada na fala do cantor. No cotidiano de Chico, não há a presença de críticas sociais, pois, mesmo quando se apropria do refrão modificado por Criolo, há uma diminuição da carga semântica dos versos, neutralizando a contundência da mensagem" (Stive Vicente Ferreira); "Chico Buarque apenas faz uma apresentação da homenagem a Criolo, canta a versão do rapper para o refrão e depois os versos originais; ele não faz outros versos que tratem da violência abordada por Criolo em sua versão" (Giovanni Santa Rosa). Sobre os impasses da obra recente de Chico Buarque, ver ainda Paulo da Costa e SILVA (14 jun. 2012) e Carlos Augusto Bonifácio LEITE (2014). Poderia se considerar que "Rap de Cálice" é mais um capítulo de $O$ fim da canção. No meu entendimento, contudo, já se gastou mais tempo do que o necessário nesse debate, o que se comprova por sua transformação em slogan com bom apelo comercial junto a pessoas educadas ("o que é uma categoria social, mais do que um elogio", segundo Roberto Schwarz). Exemplo em contrário foi dado pelo Coletivo MPB que, com bastante lucidez, conduziu a crítica de $O$ fim da canção para a observação de aspectos fundamentais da cultura no Brasil; vale a pena destacar dois deles: a) o "caráter político [do] encontro entre a lógica própria da indústria cultural e uma geração de músicos e compositores comprometida não apenas com a renovação da MPB, mas também, em boa parte, com a própria transformação do país" na década de 1960; b) o fato de que "o público militante dos festivais de TV dos anos 1960 foi criado antes dos festivais, foi criado pelos musicais e shows estudantis"; a observação desses aspectos deu suporte a uma pergunta essencial: "que forma de organização coletiva poderia hoje desempenhar um papel semelhante ao que tiveram os musicais estudantis da década de 1960?" (COLETIVO MPB, 2006).
} 
BAHIANA, Ana Maria. A paz doméstica de Gilberto Gil. In: Nada será como antes: $\mathrm{MPB}$ nos anos 70 - 30 anos depois. Ed. revista. Rio de Janeira: Editora Senac Rio, 2006, p. 82-94.

BENJAMIN, Walter. Charles Baudelaire um lírico no auge do capitalismo. Trad. J. M. Barbosa; H. A. Baptista. 3. ed., 2. reimpressão. São Paulo: Brasiliense, 2000.

BRITTO, Jomard Muniz de. Do modernismo à bossa nova. Rio de Janeiro: Civilização Brasileira, 1966.

CANDIDO, Antonio. Iniciação à literatura brasileira (Resumo para principiantes). 2. ed. São Paulo: Humanitas, 1998.

. Formação da literatura brasileira: momentos decisivos. 9. ed. Belo Horizonte:

Ed. Itatiaia, 2000. 2 volumes.

CARVALHO, Gilberto de. Chico Buarque: análise poético-musical. 2. ed. Rio de Janeiro: Codecri, 1982.

CASTRO, Ruy. Chega de saudade: a história e as histórias da bossa nova. São Paulo: Companhia das Letras, 1999.

COSTA, Caio Túlio. Cale-se. São Paulo: A Girafa Editora, 2003.

COSTA, Iná Camargo. A hora do teatro épico no Brasil. Rio de Janeiro: Paz e Terra/ Graal, 1996.

COUTINHO, Carlos Nelson. Cultura e sociedade no Brasil. In: BRAZ, Marcelo (org.) Samba, cultura e sociedade: sambistas e trabalhadores entre a "questão social" e a questão cultural no Brasil. São Paulo: Expressão Popular, 2013, p. 31-62.

DIAS, Marcia Tosta. Os donos da voz: indústria fonográfica brasileira e mundialização da cultura. 2. ed. São Paulo: Boitempo, 2008.

GARCIA, Miliandre. Do teatro militante à música engajada: a experiência do CPC da UNE (1958-1964). São Paulo: Editora Fundação Perseu Abramo, 2007.

GIL, Gilberto. Gilberto Gil: todas as letras: incluindo letras comentadas pelo compositor. Org. Carlos Rennó; colaboração Marcelo Fróes. 2. ed., revista e ampliada. São Paulo: Companhia das Letras, 2003.

KEHL, Maria Rita. Fetichismo. In: BUCCI, Eugênio; KEHL, Maria Rita. Videologias. São Paulo: Boitempo, 2004, p. 63-84. 
MENESES, Adélia Bezerra de. Desenho mágico: poesia e política em Chico Buarque. 2. ed. São Paulo: Ateliê Editorial, 2000.

NAPOLITANO, Marcos. "Seguindo a canção": engajamento político e indústria cultural na MPB (1959-1969). São Paulo: Annablume/ Fapesp, 2001.

. A "estranha derrota": os comunistas e a resistência cultural ao regime militar (1964-1968). In: NAPOLITANO, Marcos; CZAJKA, Rodrigo; MOTTA, Rodrigo Patto Sá (orgs.). Comunistas brasileiros: cultura política e produção cultural. Belo Horizonte: Editora UFMG, 2013, p. 317-338.

ORTIZ, Renato. A moderna tradição brasileira: cultura brasileira e indústria cultural. 5. ed., 3. reimpressão. São Paulo: Brasiliense, 2001.

. Revisitando o tempo dos militares. In: REIS, Daniel Aarão; RIDENTI, Marcelo; MOTTA, Rodrigo Patto Sá (orgs.). A ditadura que mudou o Brasil: 50 anos do golpe de 1964. $1^{\mathrm{a}}$ reimpressão. Rio de Janeiro: Zahar, 2014, p. 112-127.

PROENÇA, M. Cavalcanti. Ritmo e poesia. Rio de Janeiro: Organização Simões, 1955.

REIS, Aquiles Rique. “(...) Você corta um verso eu escrevo outro”. In: O gogó de Aquiles: textos. São Paulo: A Girafa Editora, 2004, p. 89-92.

REIS FILHO, Daniel Aarão. Ditadura e democracia no Brasil: do golpe de 1964 à Constituição de 1988. Rio de Janeiro: Zahar, 2014.

ROSENFELD, Anatol. A teoria dos gêneros. In: O teatro épico. 4. ed. São Paulo: Perspectiva, 2000a, p. 13-36.

. Beethoven e o Romantismo. In: Texto/Contexto II. São Paulo: Perspectiva, 2000b, p. 275-282.

SCHWARZ, Roberto. Cultura e política, 1964-1969. In: O pai de família e outros estudos. 2. ed. Rio de Janeiro: Paz e Terra, 1992, p. 61-92.

SILVA, Alberto Moby Ribeiro da. Sinal fechado: a música popular brasileira sob censura (1937-45 / 1969-78). 2ª ed., 1ª reimpressão. Rio de Janeiro: Apicuri, 2008.

TERRA, Renato; CALIL, Ricardo. Uma noite em 67. São Paulo: Planeta, 2013.

VELOSO, Caetano. O mundo não é chato. Org. Eucanaã Ferraz. São Paulo: Companhia das Letras, 2005.

VENTURA, Zuenir. O vazio cultural; A falta de ar. In: GASPARI, Elio; HOLLANDA, Heloisa Buarque de; VENTURA, Zuenir. Cultura em trânsito: da repressão à abertura. Rio de Janeiro: Aeroplano, 2000, p. 40-85. 
WERNECK, Humberto. Gol de letras. In: BUARQUE, Chico. Chico Buarque, letra e música. 2. ed., 4. reimpressão. São Paulo: Companhia das Letras, 2000, p. 9-262.

\section{Periódicos acadêmicos e Anais de congressos}

BROWN, Nicholas. Brecht eu misturo com Caetano: citação, mercado e forma musical. Revista do Instituto de Estudos Brasileiros, São Paulo, n. 59, 2014. Disponível em: <http:/ / www.scielo.br/pdf/rieb/n59/0020-3874-rieb-59-00149.pdf>. Acesso em: 10 dez. 2014.

LEITE, Antonio Eleilson. Marcos fundamentais da Literatura Periférica em São Paulo. Revista de Estudos Culturais, São Paulo, n. 1, sem paginação, jun. 2014. Disponível em: <http:// www.each.usp.br/revistaec/?q=revista/1/marcos-fundamentais-daliteratura-perif\% C3\%A9rica-em-s\%C3\%A3o-paulo>. Acesso em: 18 jun. 2014.

LEITE, Carlos Augusto Bonifácio. Sobre o peso de si e maestrias: uma análise de parte da cena atual da canção popular brasileira. Revista do Instituto de Estudos Brasileiros, São Paulo, n. 59, 2014. Disponível em:

<http://www.scielo.br/pdf/rieb/n59/0020-3874-rieb-59-00213.pdf>. Acesso em: 10 dez. 2014.

NAPOLITANO, Marcos. “A música popular brasileira (MPB) dos anos 70: resistência política e consumo cultural". Actas del V Congresso Latinoamericano IASPM, 2002.

Disponível em:

<http://www.educadores.diaadia.pr.gov.br/arquivos/File/fevereiro2012/historia_ artigos/2napolitano70_artigo.pdf>. Acesso em: 10 set. 2009.

. MPB: a trilha sonora da abertura política (1975/1982). Estudos avançados, São Paulo, vol. 24, n. 69, p. 389-402, 2010.

PIMENTEL, Spensy. O Hip Hop brasileira assume a paternidade: entrevista com GOG. Cultura e pensamento, [Salvador?], n. 3, p. 112-124, dez. 2007.

\section{Dissertação acadêmica}

TEPERMAN, Ricardo Indig. Tem que ter suingue: batalhas de freestyle no metrô Santa Cruz. Dissertação (Mestrado em Antropologia Social) - FFLCH-USP, São Paulo, 2011.

\section{Imprensa}

AMARAL, Zózimo Barroso do. Vaivém. Jornal do Brasil, Caderno B, 29 abr. 1973, p. 3. . “Cálice”. Jornal do Brasil, Caderno B, 7 mai. 1973, p. 3.

BUARQUE, Chico. Entrevista 365: Chico Buarque cantor poeta compositor e escritor. 365 - Seleção de leitura e informação, São Paulo, vol. 1, n. 2, p. 297-304, 1976. 
COLEÇÃO JOVEM GUARDA. Reportagem, São Paulo, ano I, n. 9, p. 171, dez. 1966.

FOLHA DE S. PAULO. A bronca de Chico. O banho de Elis. Caderno Ilustrada, p. 35, 16 mai. 1973. Autor identificado como "IM".

. O corte do som: de quem é a culpa?. Caderno Ilustrada, p. 23, 18 mai. 1973.

. Seagram fecha compra da Polygram. Caderno Dinheiro, p. 2, 22 mai. 1998.

. Painel S/A: Alvos definidos. Caderno Dinheiro, p. 2, 11 nov. 1998.

. Valor das fusões e aquisições tem queda de quase $40 \%$ no trimestre. Caderno Dinheiro, p. B6, 1 jul. 2000.

FREIRE, Roberto. Chico dá samba. Reportagem, São Paulo, ano I, n. 9, p. 68-76, dez. 1966.

HUNGRIA, Julio. Música Popular. Jornal do Brasil, Caderno B, 13 mai. 1973, p. 14.

JORNAL DO BRASIL. Chico Buarque e Gilberto Gil cantam juntos pela primeira vez em São Paulo. $1^{\circ}$ Caderno, p. 10, 10 mai. 1973.

15 mai. 1973.

. O CÁLICE da discórdia; Phono 73 o festival sem competição. Caderno B, p. 4,

NISHIMURA, Danielle. Criado no Grajaú, MC Criolo ganha o mundo e arrasta multidões em seus shows. CompanySul, São Paulo, n. 59, p. 21-24, out. 2013.

PRETO, Marcus. O pensar musicado de Criolo (entrevista). Cult, São Paulo, n. 183, p. 6-13, set. 2013.

HECKLER, Barbara. “A sociedade exige mais coragem de quem é jovem” (entrevista com Caetano Veloso). Bravo, São Paulo, n. 162, p. 30-33, fev. 2011.

\section{Internet}

BECKER, Cacilda. Ilmo. Sr. General José Bretas Cupertino MD Chefe do Departamento de Polícia Federal (1968). Publicado em: 20 mar. 2014. Disponível em: <http://institutoaugustoboal.files.wordpress.com/2014/03/carta-de-cacilda.pdf>. Acesso em: 22 set. 2014.

BOAL, Augusto. Que pensa você da arte de esquerda? Programa da peça I Feira Paulista de Opinião (5 de junho de 1968). Publicado em: 24 nov. 2012. Disponível em: <http:/ / institutoaugustoboal.files.wordpress.com/2012/11/que-pensa-vocc3aa-daarte-de-esquerda-programa-da-feira.pdf>. Acesso em: 22 set. 2014. 
BRAZIL, Daniel. O cálice do Criolo Doido. Publicado em: 21 jul. 2011. Disponível em: <http:// www.revistamusicabrasileira.com.br/artigo/o-calice-do-criolo-doido>. Acesso em: 15 jun. 2014.

COLETIVO MPB. Chega de saudade. Publicado em jan. 2006. Disponível em: <http://p.php.uol.com.br/tropico/html/textos/2719,1.shl>. Acesso em: 23 fev. 2008.

NOGUEIRA, Bruno Torturra. Criolo (entrevista). Publicado em: 23 set. 2011. Disponível em: <http:/ / revistatrip.uol.com.br/revista/203/paginasnegras/criolo.html>. Acesso em: 15 jun. 2014.

RINHA dos MC's. Disponível em: <http://rinhadosmcs.com.br>. Acesso em: 15 jun. 2014.

SILVA, Paulo da Costa e. Chico e os olhos do carrasco: de Paratodos a Parapoucos. Publicado em: 14 jun. 2012. Disponível em:

<http:/ / www.blogdoims.com.br/ims/chico-e-os-olhos-do-carrasco-de-paratodos-aparapoucos-por-paulo-da-costa-e-silva/>. Acesso em: 4 jun. 2014.

UNIVERSAL MUSIC. Histórico/Perfil. Disponível em:

<http:/ / www.abpd.org.br/sobre_gravadora.asp?g=17>. Acesso em: 24 jul. 2014.

VILLAÇA, Túlio. A melodia do rap - Criolo. Publicado em: 24 mai. 2014. Disponível em: <http://tuliovillaca.wordpress.com/2014/05/24/a-melodia-do-rap-criolo/>. Acesso em: 15 jun. 2014.

\section{Referências sonoras e audiovisuais}

BUARQUE, Chico. Paratodos. Chico Buarque. In: BUARQUE, Chico. Paratodos. BMG Ariola/ RCA, V120.046, 1993. 1 CD.

. Vai passar. Direção Roberto de Oliveira. EMI, 336933 9, 2005. 1 DVD.

. Rap de Cálice. Chico Buarque. In: BUARQUE, Chico. Na carreira. Biscoito Fino, BF 173-3, 2012. 1 DVD.

BUARQUE, Chico e NASCIMENTO, Milton. Cálice. Gilberto Gil, Chico Buarque. In: BUARQUE, Chico. Chico Buarque. Philips/ PolyGram, 6349 398, 1978. 1 LP, lado A, faixa 2.

CRIOLO DOIDO. Ainda há tempo. SkyBlue Music, SKY 5273, 2006. 1 CD.

. Criolo Doido - Cálice. Publicado em: 9 set. 2010. Disponível em:

<http:/ / www.youtube.com/watch?v=akZY0-6Rs0A>. Acesso em: 26 mai. 2014. 
GIL, Gilberto. Gilberto Gil ao vivo na USP 1973. Gravado em: 26 mai. 1973.

Disponível em: <http:/ / www.youtube.com/watch?v=dIwKGsjRqGQ>. Acesso em: 19 jun. 2014.

Gilberto Gil explica a música "Cálice”. Publicado em: 15 abr. 2013.

Disponível em: <http:/ / www.youtube.com/watch?v=8CnSiaP-jL4>. Acesso em: 19 jun. 2014.

VÁRIOS. Phono 73: o canto de um povo. Universal Music, 60249824412, 2005. 2 CDs, 1 DVD. 